\title{
Large Scale Dynamic Testing of Rock Support System at Kiirunavaara Underground Mine
}

\author{
Shahin Shirzadegan ${ }^{1}$ (1) $\cdot$ Erling Nordlund $^{1} \cdot$ Ping Zhang $^{1}$
}

Received: 12 June 2015 / Accepted: 29 February 2016/Published online: 17 March 2016

(c) The Author(s) 2016. This article is published with open access at Springerlink.com

\begin{abstract}
A series of five large scale dynamic tests were conducted at the LKAB Kiirunavaara mine using explosives to generate the dynamic load on the support system. This was done with the aim of developing a testing methodology for in situ testing of ground support. Furthermore, the response of the installed rock support system to strong dynamic loading was evaluated. The tests included ground motion measurements, fracture investigation, ground and support motion imaging, as well as deformation measurements. The results indicated that the relation between the burden and the used amount of explosive had a vital role in either reducing or involving the effect of the detonation gases in the test results. In addition, the type of explosive which was used in the tests had a great impact on minimising the gas expansion effects. Higher peak particle velocities were measured compared to those of similar large scale tests carried out in other countries. However, the level of induced damage was limited to a fractured zone behind the support system and propagation of cracks in the shotcrete. Measured peak particle velocities were used to calculate the kinetic energy transmitted to the fractured zone of the test wall. The energy absorption by the Swellex, reinforced shotcrete and weld mesh was estimated by measuring the elongation/deflection of the support elements and relating these measurements to previously
\end{abstract}

Shahin Shirzadegan

shahin.shirzadegan@1tu.se

Erling Nordlund

erling.nordlund@1tu.se

Ping Zhang

ping.zhang@ltu.se

1 Division of mining and Geotechnical Engineering, Luleå University of Technology, Luleå, Sweden conducted laboratory tests. The comparison of maximum estimated energy absorbed by support system with the maximum estimated kinetic energy indicated that as the support system is still functional, the energy is partly reflected back to the surrounding rock. The results of the measurements in Tests 1, 2, 4 and 5 are presented in this paper and the methodology used to design the tests is discussed.

Keywords In situ dynamics testing - Peak particle velocity $\cdot$ Rock support system $\cdot$ Fibre-reinforced shotcrete $\cdot$ Weld mesh $\cdot$ Swellex

\section{List of Symbols}

$A_{i} \quad$ Accelerometers identity (-)

$D \quad$ Dimension (-)

$d_{\mathrm{C}} \quad$ Charge diameter $(\mathrm{mm})$

$d_{\mathrm{C} 1} \quad$ Charge diameter (located in the middle of blasthole) (mm)

$d_{\mathrm{C} 2} \quad$ Charge diameter (located at the end of blasthole) (mm)

$E \quad$ Energy $\left(\mathrm{kJ} / \mathrm{m}^{2}\right)$

$G_{i} \quad$ Gas pressure sensor identity (-)

I Observation borehole identity (-)

$J_{\mathrm{a}} \quad$ Joint alteration number (-)

$J_{\mathrm{r}} \quad$ Joint roughness number $(-)$

$M_{\mathrm{L}} \quad$ Local magnitude (-)

$Q \quad$ Quality of the rock mass (-)

$R_{\mathrm{C}} \quad$ Nominal reflection coefficient (-)

$T_{i} \quad$ Coaxial cable identity (-)

$t \quad$ Depth of failure $(\mathrm{m})$

$v$ Particle velocity $(\mathrm{m} / \mathrm{s})$

$Z_{1} \quad$ Input impedance (ohm)

$Z_{2} \quad$ Output impedance (ohm)

$\rho \quad$ Rock mass density $\left(\mathrm{kg} / \mathrm{m}^{3}\right)$ 


\section{Introduction}

The problems induced by seismic events have necessitated implementing remedies to mitigate the associated seismicity risks. Three measures that can reduce the seismicity risks are described as reducing exposure of personnel, changes to mine design, layout and extraction sequences, and using dynamically strong ground support systems (Potvin et al. 2010). However, using ground support systems which are capable of withstanding strong dynamic loads to minimise the associated damages and increase the safety at the work site has been shown to be most favourable.

The conventional design approach of rock support essentially consists of (1) the identification of potential failure modes and (2) a comparison of the available capacity with the driving force/demand (including dynamic components). By calculating the factor of safety or the probability of failure, the demand on the rock support can be estimated. Unfortunately, it has been concluded that it is impossible to design support systems under seismic loading conditions by using this approach, since neither the demand on a support system nor the capacity of a support system can be satisfactorily defined (Stacey 2012).

To quantify the performance of the rock support systems suitable for dynamic loading conditions, four main types of dynamic tests are considered including simulated large scale experiments by means of blasting, drop test facilities that apply an impact load on the reinforcement, laboratory tests applying dynamic loads on core samples, and passive monitoring and back analysis of case studies (Hadjigeorgiou and Potvin 2008).

This paper focuses on to develop an in situ testing method for rock support, i.e., to determine the dynamic load that causes failure to the test wall and/or support system, and to evaluate the performance of rock support systems under strong dynamic load. A number of in situ tests have been carried out in the past. Examples are (1) a number of simulated rockburst experiments which were carried out in underground mines in Western Australian (Heal et al. 2005; Heal and Potvin 2007; Heal 2010). The tests aimed to assess the performance of complete ground support systems in situ when subjected to strong ground motion. (2) Andrieux et al. (2005) conducted large scale tests at the Fraser Nickel Mine aiming to investigate the effects of a large rockburst that would occur in the vicinity of a drift supported by three different ground support systems, and in particular to assess whether or not the thin spray-on liner system has the potential to be successfully used under rockbursting conditions. (3) Ansell (2004) carried out in situ tests in which shotcrete panels were exposed to vibrations from explosive charges detonated inside the rock mass aiming to investigate the growth of the compressive strength and also to determine the final compressive and adhesive strengths of shotcrete, (4) Archibald et al. (2003) conducted a series of tests of the liner support system and investigated the use of spray-on rock lining in mitigating rockburst damage using blasting as the dynamic load. (5) Espley et al. (2002) carried out large scale tests at 175 Orebody research facility aiming at assessing the response of the surface support systems (thin spray-on liners and shotcrete) under blast-induced dynamic loads and in seismic related environments. (6) Hagan et al. (2001) conducted large scale tests in South Africa which aimed at improving mine worker safety through an improved understanding of the mine excavation site response to seismicity. The study comprised the experiment and numerical modelling (Hildyard and Milev 2001a, b) to mimic a seismic source by means of a blast, near and far field seismic monitoring (Milev et al. 2001), high-speed video filming to derive the ejection velocities (Rorke and Milev 1999), a study of rock mass conditions (fractures, joints, rock strength, etc.) before and after the blast to estimate the extent and type of damage brought about by strong ground motion (Reddy and Spottiswoode 2001) and evaluation of the support performance under dynamic loading (Haile and Le Bron 2001). (7) Tannant et al. (1994a) carried out simulated rockburst tests in the Bousquet \#2 Mine in Canada to assess the performance of a range of ground support systems under dynamic loading, but in particular, to compare the performance of shotcrete and mesh to fibre-reinforced shotcrete. (8) Tannant et al. (1994b) conducted tests in the CANMET Experimental Mine in Canada with the aim to investigate the response of rockbolts to nearby blasts using three strain gauged standard end-anchored mechanical rock bolts, and (9) Ortlepp $(1969,1992)$ carried out large scale tests to compare the performance of conventional and yielding rockbolts in situ. Despite the difficulties and uncertainties with simulated seismic event tests, the method still provides the greatest validity as a significant test of rockburst support capabilities, even though it does not simulate a rockburst (Stacey 2012).

Within the framework of a research programme focused on deep mining problems at Luleå University of Technology, in situ dynamic testing of rock support using blasting as the seismic source was conducted in the Kiirunavaara underground mine, owned and operated by Luossavaara Kiirunavaara Aktiebolag (LKAB). The main purpose of the tests was to develop a large scale in situ testing method for evaluating rock support performance. This was done by exposing the rock support system to seismic waves generated by blasting and with different levels of energy. One issue specifically addressed when designing the large scale 
dynamic tests was to minimise the destructive effects of the expansion of gases generated by the blast. Therefore, the effect of gas pressure was monitored to investigate the contribution of damage from the gas expansion on the test results, and if possible rock ejection and obtaining quantitative data for modelling. Different techniques (details described in Sect. 3.2) were applied to estimate the surface velocity and deformation, the gas pressure in the burden and the development of damage such as new fractures and/ or separation/sliding along pre-existing joints inside the pillar. Collected field data and damage mapping were used to evaluate the effect of different charge concentrations on the test wall and support system. Based on collected data, kinetic energy transmitted to the fractured zone of the test wall and the energy absorbed by the support elements and surface support was estimated and the results were compared and discussed.

\section{Test Site Description}

The Kiirunavaara mine in the northern part of Sweden is an iron ore mine with an ore body that strikes nearly NorthSouth and dips $60^{\circ}$ to the East. It is about $4 \mathrm{~km}$ long and has an average thickness of $80 \mathrm{~m}$. The mining method used in the Kiirunavaara mine is large scale sublevel caving. The footwall mainly consists of Precambrian aged trachyandesite internally denoted as syenite porphyry. The hanging wall consists of rhyolite, internally denoted as quartz porphyry. The main iron ore consists of magnetite that lies between the syenite porphyries and the quartz bearing porphyries (Malmgren 2005).
Adjacent pillars between the cross-cuts 93 and 95 in the completed production block 9 on the $741 \mathrm{~m}$ level were chosen for the tests $1-5$. All of the tests were planned to be conducted at the chosen site because (1) no mining activity was taking place at that level, (2) the pillars were only shotcreted (3) many cross-cuts with similar rock mass conditions were available for further tests and (4) comprehensive geological investigations had been done in the area. The width of the pillars was approximately $18 \mathrm{~m}$ and the cross-cuts were about $7 \mathrm{~m}$ wide and $5.2 \mathrm{~m}$ high. According to Andersson (2010), the rock types in the test area have traditionally been referred to as syenite porphyries, including a nodular variety (Geijer 1910), mainly consisting of trachytes to trachyandesites (Ekström and Ekström 1997) of variable character and degree of alteration. Figure 1 illustrates the location and rock types in cross-cuts 93 and 95 , where tests 1-5 were carried out.

The rock mass in the area was very blocky and the geological strength index (GSI) values were estimated to lie mostly within the range of $40-50$, with joint quality from good to acceptable (Andersson 2010). However, the southern pillar in cross-cut 93 (location of Test 2) was more jointed and included significant clay fillings which lowered the GSI value locally to 30. Dripping water was present over the whole area suggesting that the rock mass was hydraulically conductive.

The area was characterised by an intense network of structures in many directions. Eighty joints were mapped in cross-cut 93. The most significant set was parallel to crosscut 93 , dipping $55^{\circ}-80^{\circ}$ to the south and perpendicular to the cross-cut with subvertical dips (Andersson 2011). In cross-cut 95, 65 joints were mapped. The cross-cut was
Fig. 1 Cross-cuts 93 and 95, site for Tests $1-5$ [extracted from the database of underground mapping at LKAB (Andersson 2010)]

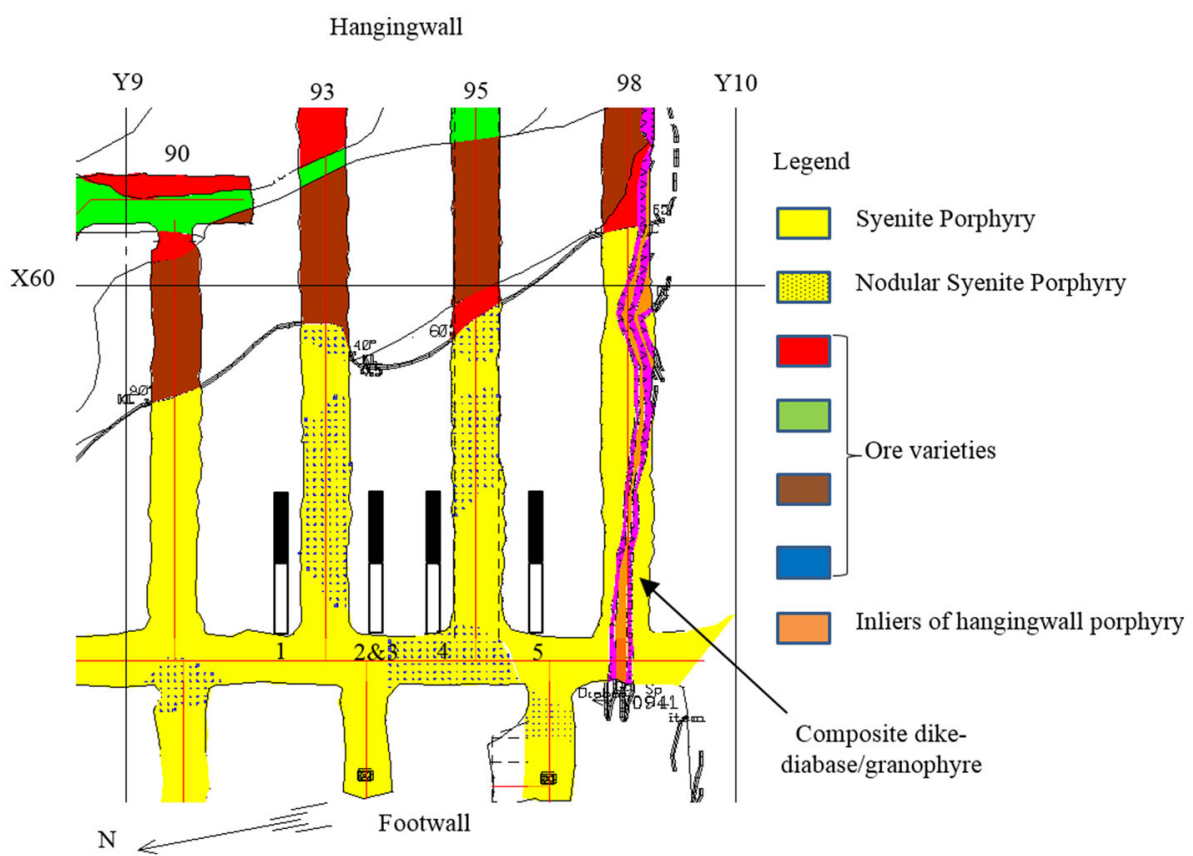



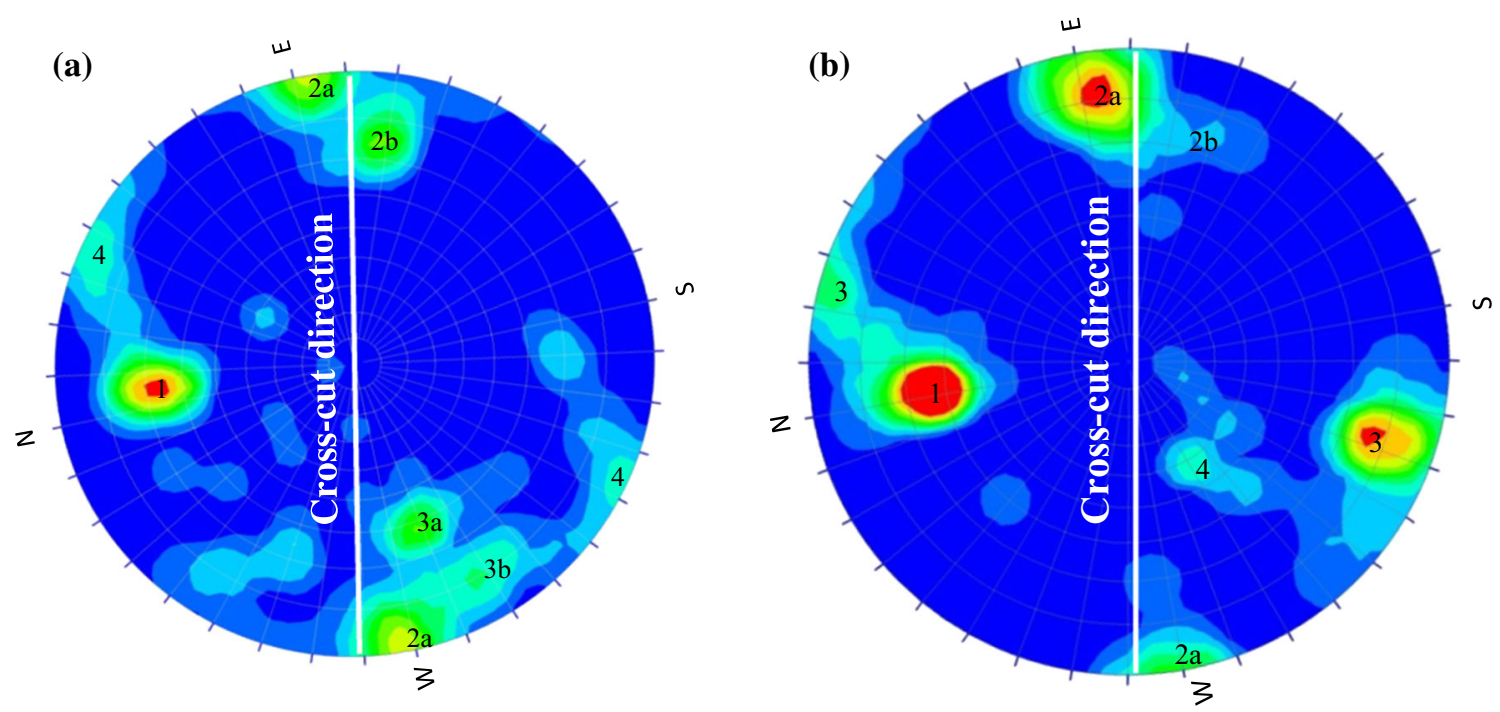

Fig. 2 Documented significant joint surfaces in the vicinity of the test site in a cross-cut 93 and b (cross-cut 95 (Andersson 2011))

dominated by joints striking (1) EW dipping $50^{\circ}-80^{\circ} \mathrm{S}$, (2) NS semi vertical, and (3) NW dipping $70^{\circ}-90^{\circ} \mathrm{NE}$. The joint spacing was generally in the range of 1-3 m. However, joint set (3) was observed with a $0.1 \mathrm{~m}$ spacing in a zone in the northern wall of cross-cut 95 (where Test 4 was carried out) which had a major impact in defining block fallouts (Andersson 2011). Figure 2 represents the pole density plots of the significant joint sets in cross-cuts 93 and 95 .

\section{Blasting Design and Instrumentation}

cThe explosive selected for the tests in the Kiirunavaara mine was a military type, NSP711, with a measured velocity of detonation (VOD) of $7931 \mathrm{~m} / \mathrm{s}$ and a density of $1500 \mathrm{~kg} /$ $\mathrm{m}^{3}$ (except in Test 3 in which bulk emulsion was used). The reason for selecting this type of explosive was the lower amount of gas production compared to commercial explosives, high VOD and a blasthole pressure resulting in more wave energy than gas expansion, a better control over the amount of explosives, and the well-known Jones-WilkinsLee (JWL equation of state) parameters for numerical analysis (Helte et al. 2006). Furthermore, four holes were drilled into the burden to measure the gas pressure in the burden. The two following sections will describe the blasting design and the monitoring instruments used in the tests.

\subsection{Blasting Design}

The design of the blast aimed at mimicking a seismic event with magnitude +3 (Richter scale) located $15 \mathrm{~m}$ from the drift. This resembles the largest seismic events that have occurred in the Kiirunavaara mine up to 2010 (Malmgren 2010) which caused serious damage to the rock mass and the rock support. The PPV was chosen as the quantity characterising the seismic event. The maximum PPV was calculated using a PPV—-magnitude — distance relationship presented by Kaiser et al. (1996). This resulted in PPVs which were approximately in a range of $1.5-3.5 \mathrm{~m} / \mathrm{s}$. The initial estimation of the amount of explosive, blasthole diameter, and burden for the first trial was based on experience from earlier studies in the Kiirunavaara mine (Olsson et al. 2009) which resulted in a theoretical burden of 3.3 and a $115 \mathrm{~mm}$ blasthole.

The tests were conducted either in the left or the right hand sidewall of the cross-cuts. The blasthole, with an approximate length of $15 \mathrm{~m}$, was drilled parallel to the cross-cut from an adjacent footwall drift. Two different charge diameters, each with a length of around $5 \mathrm{~m}$, were used in Tests 1, 2 and 5 to reduce the number of trials. The first $5 \mathrm{~m}$ were not charged nor stemmed in order to vent the gas and reduce the gas pressure. The next $5 \mathrm{~m}$ plus $5 \mathrm{~m}$ of the blasthole were charged with two different charge densities in Tests 1, 2 and 5 and only one charge density in Tests 3 and 4 . The area of the cross-cut wall in front of the higher charge diameter is denoted "high charge segment" and the area in front of the lower charge diameter is denoted "low charge segment" in this paper. Except for Test 3 (in which bulk emulsion was used as the explosive) the blasthole was charged with NSP711. The blastholes were primed at the bottom. The blasthole, charge characteristics and the effective burden are summarised in Table 1 . The burden varied along the tested sidewall due to blasthole deviation combined with the irregular profile of the tested wall. Therefore, only the average or effective 
Table 1 Summary of burden, blasthole and charge dimension in Tests 1-5

\begin{tabular}{|c|c|c|c|c|c|}
\hline Test & $\begin{array}{l}\text { Average } \\
\text { burden } \\
(\mathrm{m})\end{array}$ & $\begin{array}{l}\text { Diameter } \\
(\mathrm{mm})\end{array}$ & $\begin{array}{l}\text { Length } \\
\text { (m) }\end{array}$ & $\begin{array}{l}\text { Decoupling } \\
\text { ratio }(\%)\end{array}$ & $\begin{array}{l}\text { Charge } \\
\text { concentration } \\
(\mathrm{kg} / \mathrm{m})\end{array}$ \\
\hline \multirow[t]{4}{*}{1} & 3.7 & & & & \\
\hline & Blasthole & 115 & 15 & - & - \\
\hline & $d_{\mathrm{C} 1}$ & 76 & 5 & 66 & 6.8 \\
\hline & $d_{\mathrm{C} 2}$ & 45 & 5 & 40 & 2.4 \\
\hline \multirow[t]{4}{*}{2} & 3.9 & & & & \\
\hline & Blasthole & 152 & 15 & - & - \\
\hline & $d_{\mathrm{C} 1}$ & 76 & 5 & 50 & 6.7 \\
\hline & $d_{\mathrm{C} 2}$ & 98 & 5 & 66 & 10.9 \\
\hline \multirow[t]{3}{*}{3} & 3.9 & & & & \\
\hline & Blasthole & 152 & 15 & - & - \\
\hline & $d_{\mathrm{C}}$ & 152 & 15 & 100 & 25 \\
\hline \multirow[t]{3}{*}{4} & 2.8 & & & & \\
\hline & Blasthole & 152 & 15 & - & - \\
\hline & $d_{\mathrm{C} 1}$ & 120 & 6 & 79 & 16.4 \\
\hline \multirow[t]{4}{*}{5} & 3.3 & & & & \\
\hline & Blasthole & 152 & 16 & - & - \\
\hline & $d_{\mathrm{C} 1}$ & 94 & 5 & 62 & 10.3 \\
\hline & $d_{\mathrm{C} 2}$ & 83 & 6 & 55 & 8.5 \\
\hline
\end{tabular}

burden is listed in Table 1. A schematic diagram of the test layout and blast design are described and shown in Fig. 3. Four holes in Test 1 and two holes in Test 2 were drilled into the burden to measure the gas pressure in the burden using gas pressure sensors. The position of gas pressure sensors in Tests 1 and 2 is illustrated in Fig. 4. In all of the tests, the tested rock support consisted of $100 \mathrm{~mm}$ steel fibre-reinforced shotcrete $\left(40 \mathrm{~kg} / \mathrm{m}^{3}\right.$ steel fibre), $75 \mathrm{~mm} \times 75 \mathrm{~mm}$ weld mesh with $5.5 \mathrm{~mm}$ diameter, and Swellex rockbolts with a length of 3 and $1 \mathrm{~m}$ spacing.

\subsection{Monitoring Instruments}

The instrumentation used in Tests 1, 2 and 5 was designed to provide data for different objectives and included:

- Uniaxial shock accelerometers (PCB 350 B03) to estimate the surface velocity and displacement;

- High-speed camera (Casio EX-F1) to estimate block ejection velocity; the camera was capable of filming at a rate of 1200 frames per second;

- Displacement probes (spears) (Olsson et al. 2009) to measure the maximum displacement and velocity at certain points (where larger movements were expected) on the rock support surface;

- Laser scanning (Leica HDS 6000) to measure the surface deformation before and after each blast;

- Gas pressure transmitters (ED 517) to measure the gas pressure in the boreholes and for arrival estimation;
- Time Domain Reflectometry (TDR 100) coaxial cables to detect the development of damage such as new fractures and/or separation/sliding along pre-existing joints inside the pillar;

- Observation holes $(64 \mathrm{~mm})$ for borehole camera (Wöhler VIS 2000) logging before and after the blast;

- Dynamic displacement measurement (Sick OD Value laser sensor) to measure the displacement at different time intervals;

- Accelerometers, displacement probes (spears) and gas pressure sensors were connected to data acquisition units with 32 channels. Type of instrument for Test 1 was Dash 2032 with a sampling rate of $250 \mathrm{kHz}$, for Test 2 the DataFlex 1000 with $180 \mathrm{kHz}$ sampling rate, and for Test 5 PXIe-1073 with PXIe-4300 card (250 kHz sampling rate).

Table 2 summarises the used monitoring instruments in Tests 1, 2 and 5, and Fig. 5a, b shows the layout of the ground motion monitoring instrumentation used in these tests. There is a slight difference in the number of accelerometers and other monitoring instruments between Tests 1 and 2 . In Test 5, only three accelerometers, two in the middle of the high charge segment and one in the middle of the low charge segment, were used. In Tests 3 and 4 no instruments (except one high-speed camera) were installed. The reason for not using monitoring instruments in Tests 3 and 4 and only a few instruments in Test 5 was to increase the pace of the process to design the optimal burden and to estimate the optimum amount of charge concentration.

\section{Field Tests Results}

Damage mapping of the tested walls were conducted after each blast. Post-blast observations of the tested support system in Test 1 showed that cracks with a width of up to $5 \mathrm{~mm}$ and a length of 2-3 $\mathrm{m}$ were created on the surface of the reinforced shotcrete mainly within the high charge segment $\left(d_{\mathrm{C} 1}=76 \mathrm{~mm}\right)$. No obvious damage to the rockbolts or the mesh was observed. The event magnitude of the test recorded by the mine seismic system was $M_{\mathrm{L}}=0.7$ on the local magnitude scale. An example of created cracks is presented in Fig. 6a.

Observations in Test 2 showed that cracks with widths of up to $15 \mathrm{~mm}$ and 2-3 $\mathrm{m}$ in length were formed within the high and low charge segments $\left(d_{\mathrm{C} 2}=98 \mathrm{~mm}\right.$ and $d_{\mathrm{C} 1}=76 \mathrm{~mm}$, respectively), see Fig. 6b. No obvious damage to the rockbolts or the mesh was observed and a local event magnitude of $M_{\mathrm{L}}=1$ for the test was recorded by the local seismic system. 


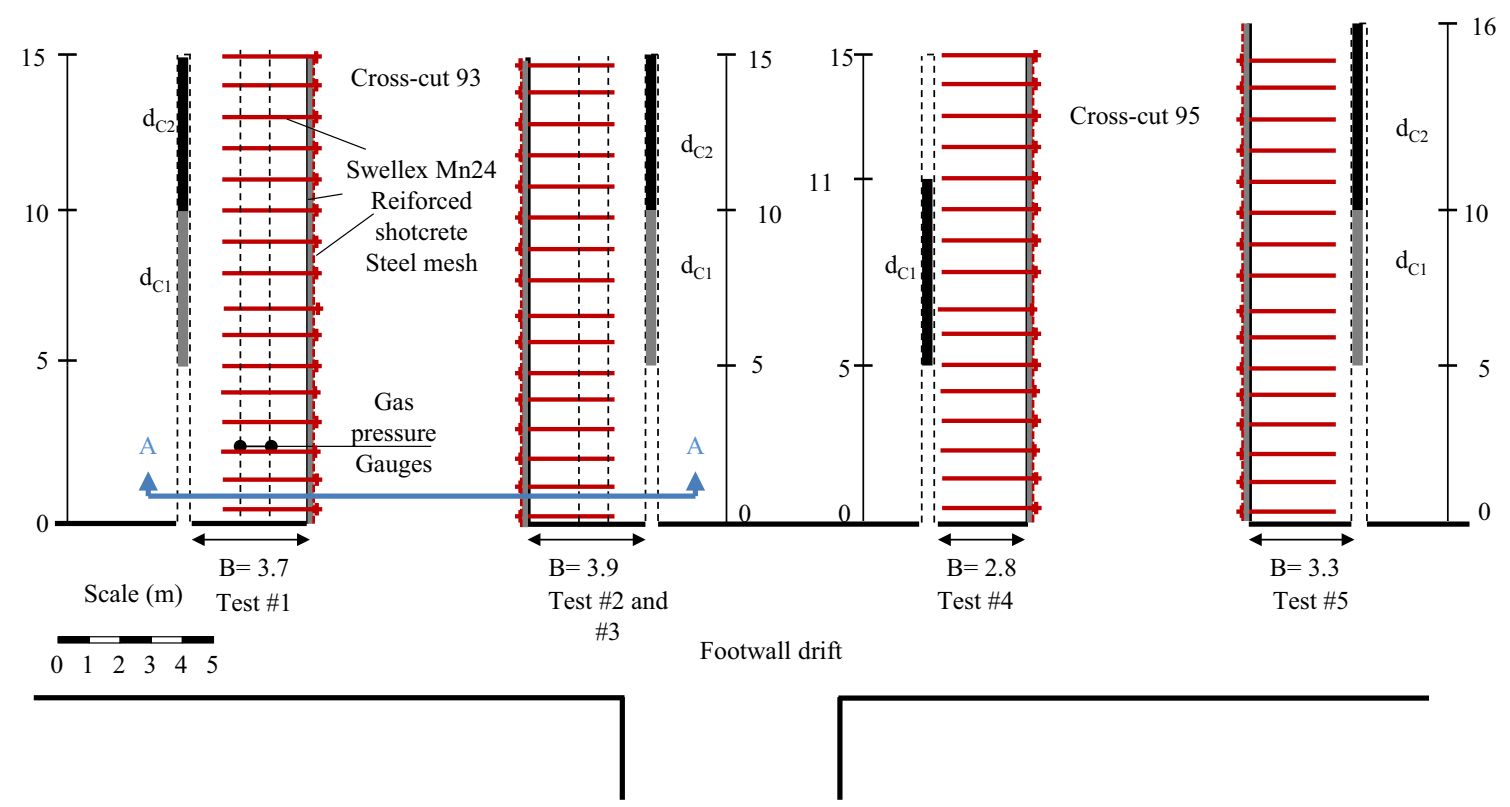

Fig. 3 Blast design in Tests 1-5

Fig. 4 Position of the gas pressure sensors Tests 1 and 2

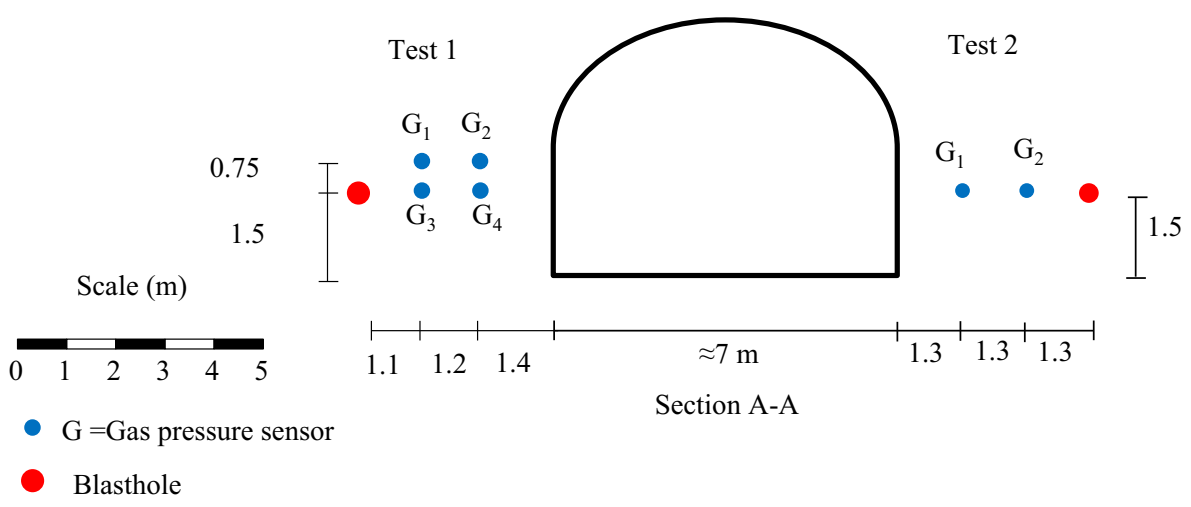

Table 2 Summary of monitoring instruments in Tests 1, 2 and 5

\begin{tabular}{ll}
\hline Test & Number of used monitoring instruments \\
\hline 1 & $\begin{array}{c}16 \text { accelerometers, } 8 \text { displacement probes, } 8 \text { coaxial cables, } 4 \\
\text { observation boreholes, laser scanning, } 4 \text { gas pressure } \\
\text { transmitters, } 1 \text { high-speed camera }\end{array}$ \\
2 & $\begin{array}{c}24 \text { accelerometers, } 4 \text { displacement probes, } 4 \text { coaxial cables, } 4 \\
\text { observation boreholes, laser scanning, dynamic displacement } \\
\text { measurements, } 2 \text { gas pressure transmitters, } 1 \text { high-speed } \\
\text { camera }\end{array}$ \\
3 & $\begin{array}{l}1 \text { high-speed camera } \\
4\end{array}$ \\
5 & 3 high-speed camera \\
\hline
\end{tabular}

The results from Test 3 are not considered in this paper because the initial conditions of this test were different from that of the other tests. Test 3 was performed by re-charging the blasthole used in Test 2 . The used explosive was bulk emulsion and the burden was fractured by Test 2 .
Completely different results were observed in Tests 4 and 5 compared to those in Tests 1 and 2. In Tests 4 and 5 the burdens were completely destroyed. Figure $6 \mathrm{c}$, d show the state of the tested wall and cross-cut after blast. The ejected rock material in Test 4 was broken into rather small pieces as a result of a high charge concentration $\left(d_{\mathrm{C} 1}=120 \mathrm{~mm}\right)$ (note that only one charge segment was used in this test), while in Test 5 , the burden was broken into large blocks of rock at both charge segments. The mesh and the rockbolts had totally lost their functionality in both of these tests. Failure mapping of the rockbolts in Test 4 was performed and the results indicated that most of the rockbolts were cut into pieces of 1-2 m of length. In $95 \%$ of the cases the face plates were detached. The local event magnitudes for Test 4 and Test 5 were $M_{\mathrm{L}}=0.8$ and $M_{\mathrm{L}}=0.9$, respectively. The local magnitude for the two tests was obtained from the mine seismic system. The following sections describe the results obtained from the installed monitoring instruments. 

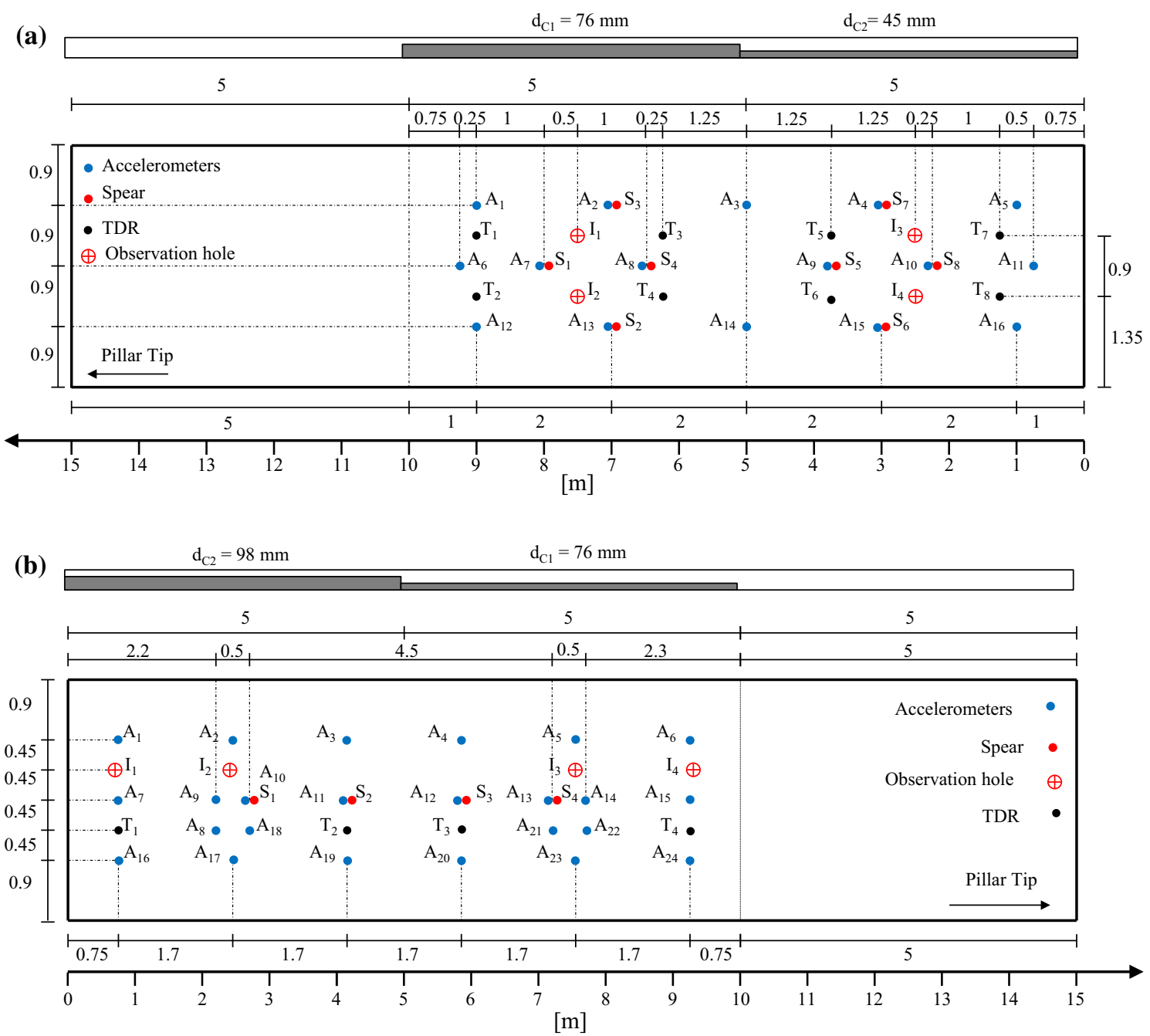

Fig. 5 Location of monitoring instruments in a Test 1 and b Test 2 (Unit: m)

\subsection{Gas Pressure Measurements}

One of the main breaking mechanisms of blasting is the expansion of detonation gases in the burden. This raises the question whether it is the waves, the gas pressure, or a combination of them that generated the damage in the rock mass and the installed support system and the ejection of rock. In general, depending on the amount of explosives and its interaction with the surrounding rock mass, blastinduced radial fractures will be formed and propagate around the blasthole. Pre-existing fractures will then become extended leading to a potential for increased gas penetration and pressure in the rock mass. Investigation of the gas pressure in the burden can help to clarify the uncertainties and increase the knowledge of the gas pressure state in the burden. The mechanism was investigated in Tests 1 and 2 by using gas pressure sensors with the sensitivity of $800 \mathrm{mV} / \mathrm{bar}$. The sensors were installed on the pillars and connected to pipes grouted into the gas measurement holes close to blastholes according to Fig. 4 in Tests 1 and 2.

The results indicated that there was a relatively high pressure (about $800 \mathrm{kPa}$ ) recorded by sensor $G_{1}$ in Test 1 $34 \mathrm{~ms}$ after the initiation and a low pressure was recorded by the rest of the sensors in both tests. Figure 7 shows the results in Test 1. By studying the behaviour of the pressure versus time signals in Fig. 7 three parts can be recognised after initiation $(t=0 \mathrm{~s})$.

- Part 1 is the arrival of the blast-induced wave to the sensors which occurs 1.4-4 ms after the charge detonation;

- Part 2 is the initiation of a negative gas pressure (pressure below normal air pressure). The air inside the hole might leak into fractures that became widened during the "heave" process of a blast. This will result in negative pressures which occurred $6-10 \mathrm{~ms}$ after charge detonation; and; 
Fig. 6 Damage in a Test 1, b Test 2, c Test 4 and d Test 5

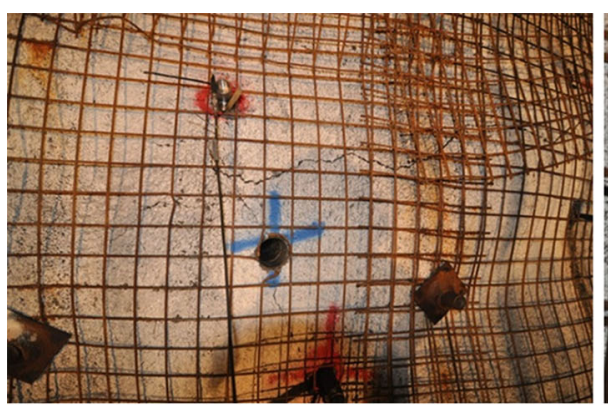

(a)

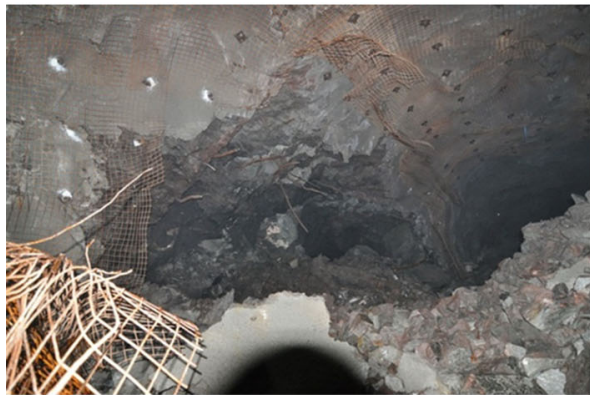

(c)

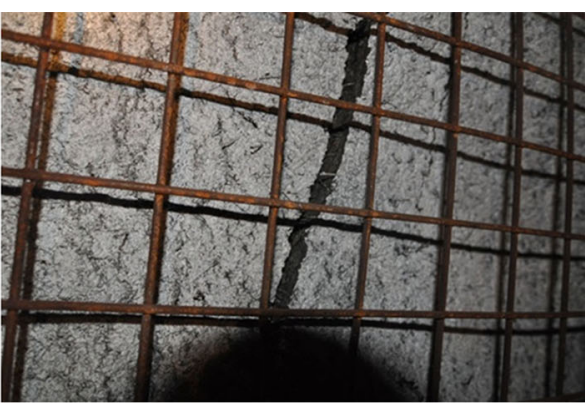

(b)

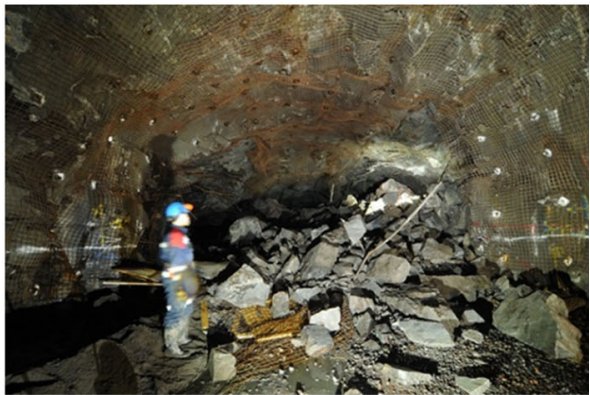

(d)

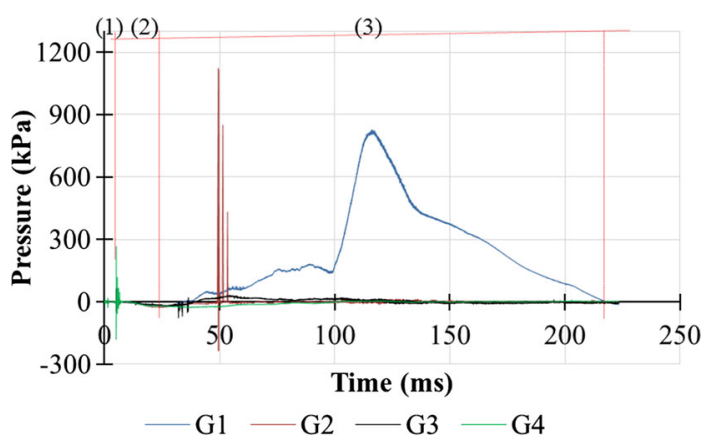

Fig. 7 Gas pressure results and three different parts after initiation in Test 1

- Part 3 represents the initiation of positive gas pressure and it occurs about 34-100 ms after detonation and was recorded by the different sensors. This part cannot be observed in the wave form measured by sensors $G_{2}$ and $G_{4}$ in Test 1 .

\subsection{Velocity Measurements}

Piezoelectric horizontal uniaxial accelerometers (PCB) were used to monitor the particle velocity near the test wall surface and to provide an indication of the characteristics of the ground motion generated by the blast. The 1Dcomponent accelerometers were installed at a depth of approximately $0.2 \mathrm{~m}$ from the surface in built-in steel housings that were grouted into approximately $0.5 \mathrm{~m}$ long and $50 \mathrm{~mm}$ diameter drilled holes oriented perpendicular to the test wall. In Test 2 , four accelerometers $\left(A_{18}\right.$ and $A_{21}$ $0.75 \mathrm{~m}$ and $A_{8}$ and $A_{22} 1.5 \mathrm{~m}$ ) were installed in the burden, to measure the particle velocity and displacement at different distances from the free surface. All accelerometers were connected to the data recorder unit via coaxial cables. The particle velocities obtained by integrating the acceleration records from each accelerometer installed on the test wall in Tests 1, and 2 are presented in Fig. 8.

None of the accelerometers were dislodged from the test wall in Tests 1 and 2, while in Test 5 the complete destruction of the burden resulted in the loss of the accelerometers. However, the waves were recorded satisfactorily before the burden was destroyed. Three accelerometers installed in Test 5 showed a range of PPV between 5.9 and $7.1 \mathrm{~m} / \mathrm{s}$. A PPV contour for kinetic energy evaluations in Tests 1 and 2 is presented in Fig. 9.

\subsection{Displacement Measurements}

Several kinds of instruments were used to measure the displacement of the test wall and the support system in Tests 1 and 2. The installation points of the accelerometers on the test wall, presented in Fig. 8, were selected primarily to record the particle velocity but also for an attempt to calculate the displacement of the tested wall. A final range of displacements was estimated at the selected points using the results from the different displacement measurement methods. This provided a range of displacements 


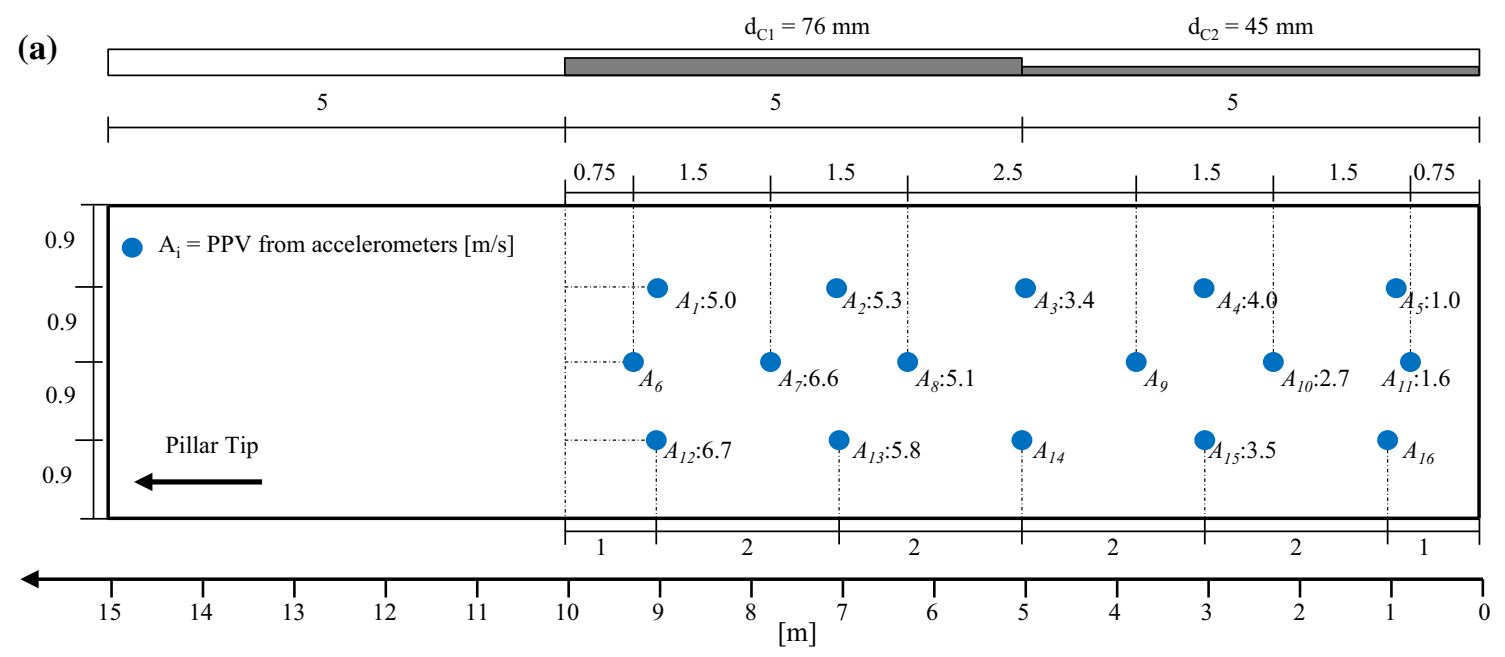

(b)
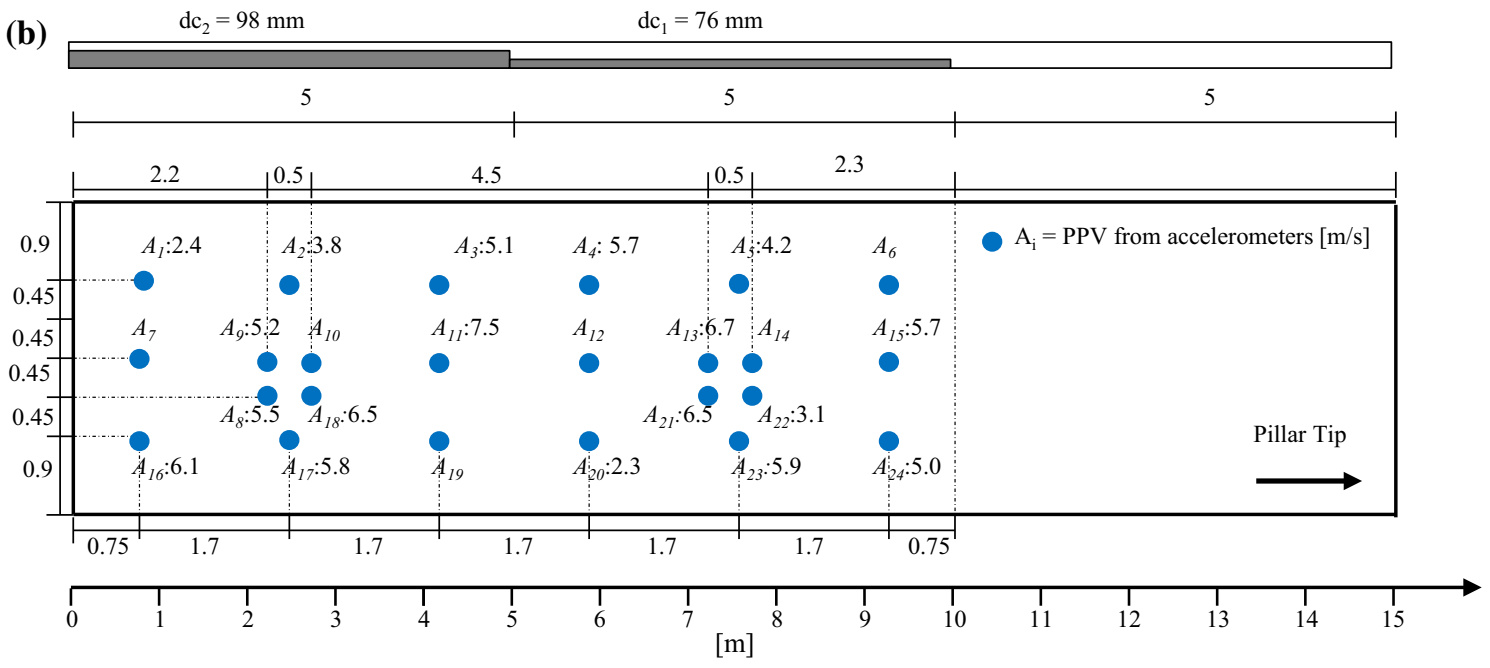

Fig. 8 Measured PPV by each accelerometer in a Test 1 and b Test 2. The PPV unit is $\mathrm{m} / \mathrm{s}$

for the support system in Tests 1 and 2 for each charge density segment. Depending on the type of instrument, measurements were carried out either "before and after" or at the time of the blasting.

A laser scanner was used to scan the surface of the test wall before and after the blast to estimate the displacement of the surface and the support system. Using this method, the displacement at the points close to the installation points of the accelerometers was estimated. Figures 10 and 11 show the scan result of the test wall in Tests 1 and 2. It is clear that the highly influenced areas of the test wall and support system are located mainly within the segments with a charge diameter greater than $76 \mathrm{~mm}$.

Built-in displacement probes (spears) (Olsson et al. 2009) were used as another method to measure the ground motion. The positions of the probes can be found in Fig. 12a. The instrument was constructed of a $0.5 \mathrm{~m}$ long cylindrical steel housing including four coaxial cables inside the housing with separation of $20 \mathrm{~mm}$. Figure $12 \mathrm{~b}$ shows the setup of the displacement probes. An impact rod (spear) $2 \mathrm{~m}$ in length was mounted between the housing and the test wall to transfer the movement induced by the blast-induced wave on the test wall to the gauges and recording unit that the co-axial cables were connected to. The instruments were installed at heights of $0.9,1.8$ and $2.7 \mathrm{~m}$ to provide the best coverage of the test wall. The probes were installed close to the installation point of the accelerometers.

Two short range distance laser sensors which provide accurate distance measurements were used to measure the dynamic displacement of the test wall at two points on the shotcrete in Test 2. As it is shown in Fig. 13a, the tripods for the lasers were located close to and at the middle of the test wall. As the results provided by laser B were distorted, only the results from laser A were evaluated and the data is presented in Fig. 13b. The signal during the first $50 \mathrm{~ms}$ 

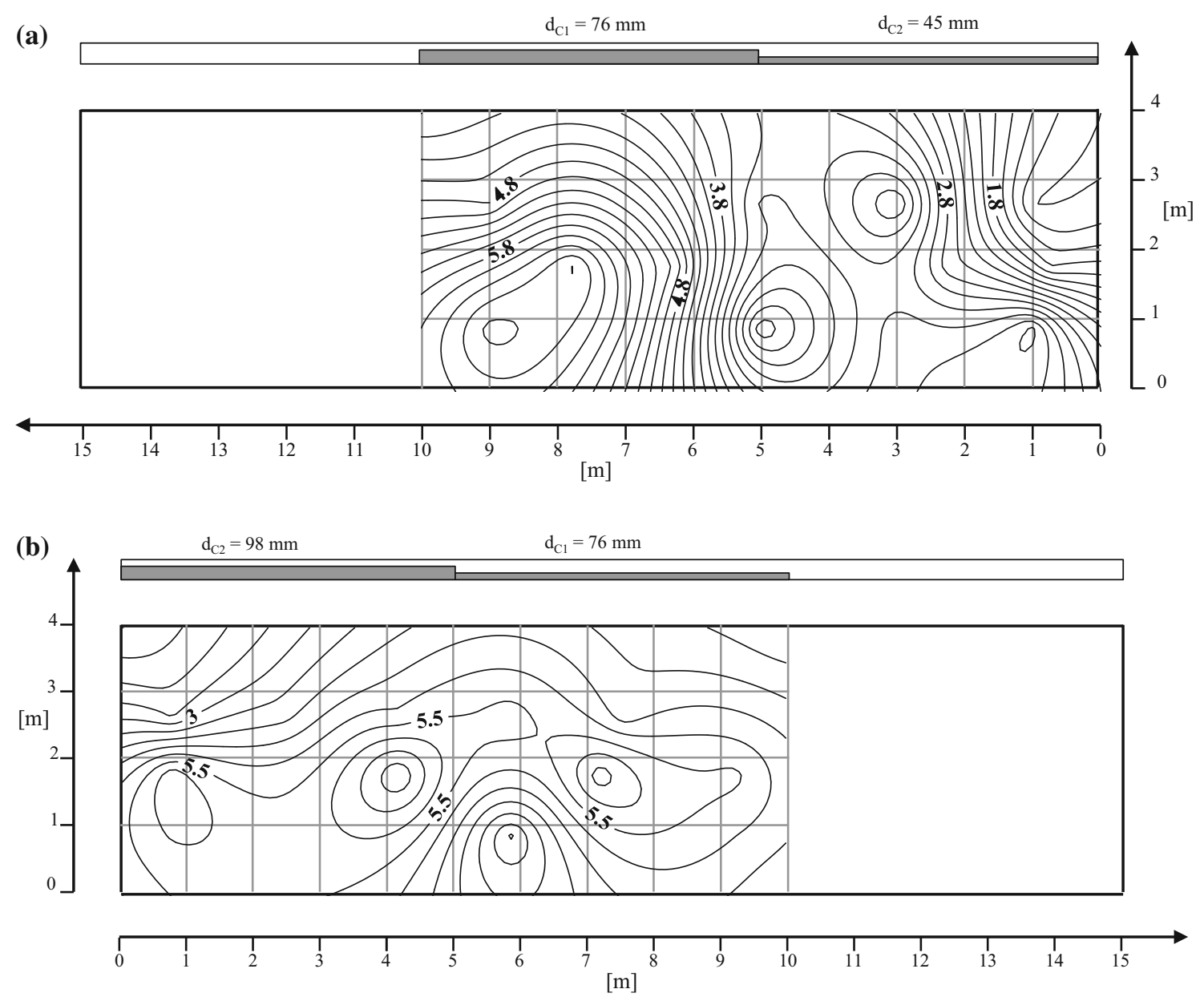

Fig. 9 PPV contour in a Test 1 , and b Test 2

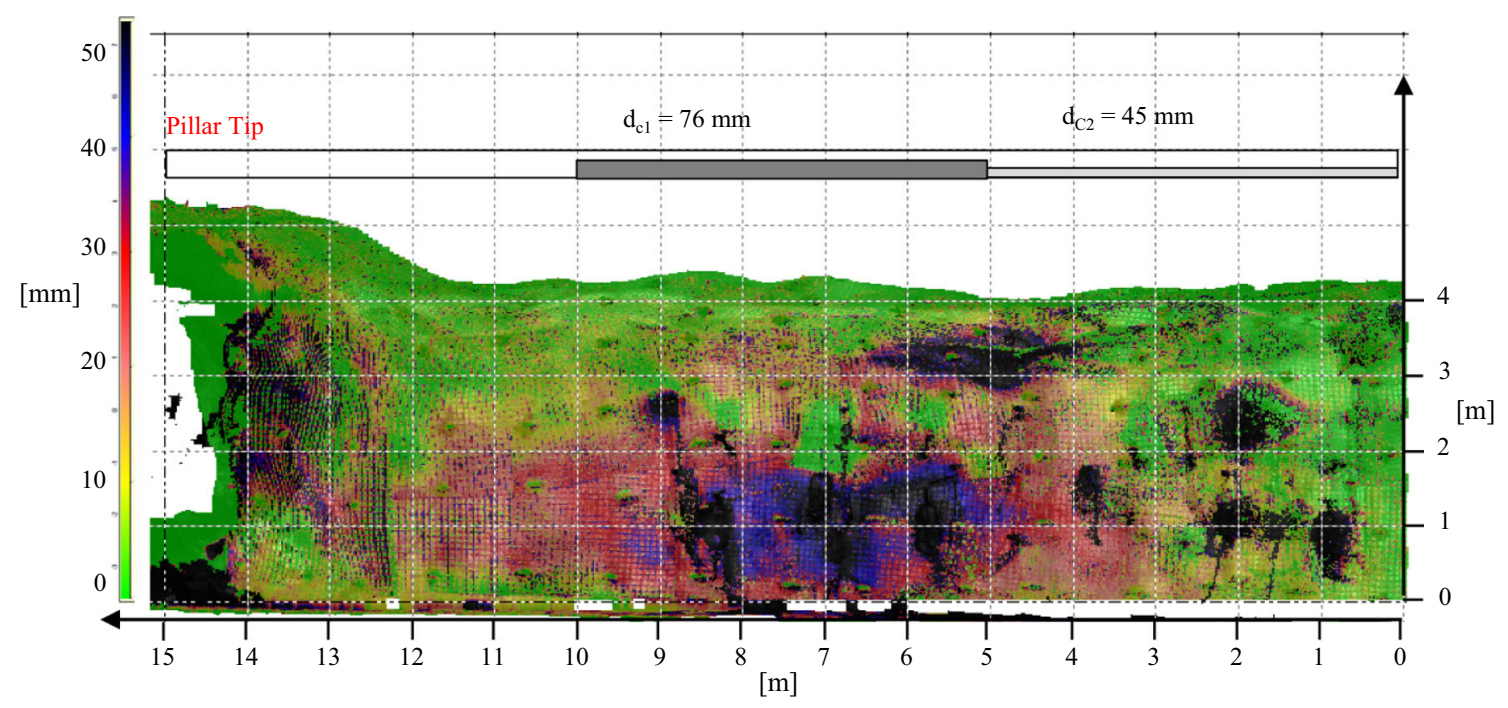

Fig. 10 Displacement of the tested wall measured by laser scanning in Test 1 


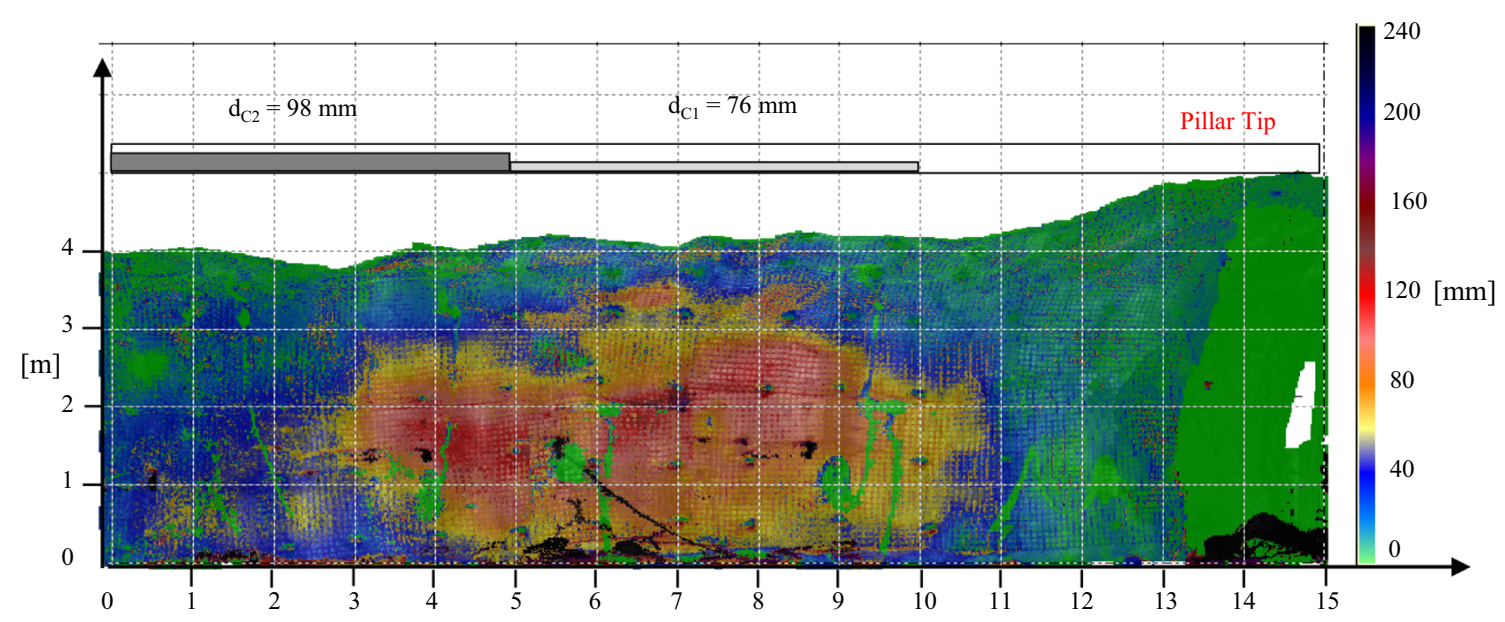

Fig. 11 Displacement of the tested wall measured by laser scanning in Test 2

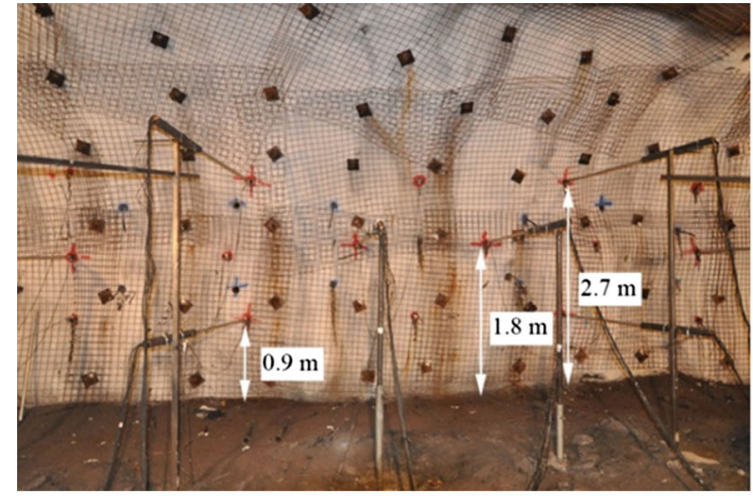

(a)

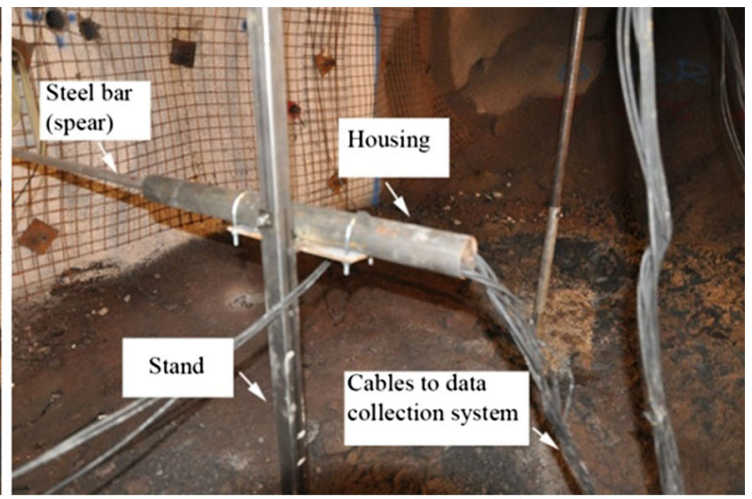

(b)

Fig. 12 Displacement probes in Tests 1 and 2

after the detonation shows the displacement of the test wall at different times of the test. The displacement at the measuring point reached to the maximum value of $70 \mathrm{~mm}$ at $30 \mathrm{~ms}$, and then decreased to $55 \mathrm{~mm}$ at $50 \mathrm{~ms}$. The signal was disturbed since the tripod moved during the test due to air shock after $50 \mathrm{~ms}$. A non-elastic deformation can be observed in the signal. A final displacement of $55 \mathrm{~mm}$ was measured by this sensor.

The second integration of the acceleration data was used to estimate the amount of displacement at the installation point of the accelerometers. The final range of displacement at each charge segment in Tests 1 and 2 are summarised in Table 3.

\subsection{High-Speed Camera}

A high-speed camera was used to record each test. The aim was to evaluate the rock ejection velocity from the test wall and compare the results with the PPV measured on the surface wall. The camera was capable of recording at a rate of 1200 frames per second. However, due to insufficient light in the cross-cut, the frame rate was decreased to 300 . This frame rate provided a time interval of $3.3 \mathrm{~ms}$ per frame. The camera was placed in a camera housing to be protected from flying stones and the axis of the objective had an angle of $20^{\circ}$ to the surface of the wall. The housing was filled with sponges to reduce the vibrations generated by air shock.

In order to obtain a video with high resolution, the light condition along the cross-cut was improved by using 8 light panels built by shock tubes. Different initiation was set for the eight light panels so four of them were initiated $15 \mathrm{~ms}$ before the charge detonation and the other four initiated after the first four ( $35 \mathrm{~ms}$ after the detonation) to obtain a longer duration of light in the cross-cut. The method facilitated the recording of a video with acceptable duration and good quality for further analysis.

Since Tests 1 and 2 did not show any ejection from the test walls the video was only used to evaluate the surface velocity, the displacement within the high charge segment 


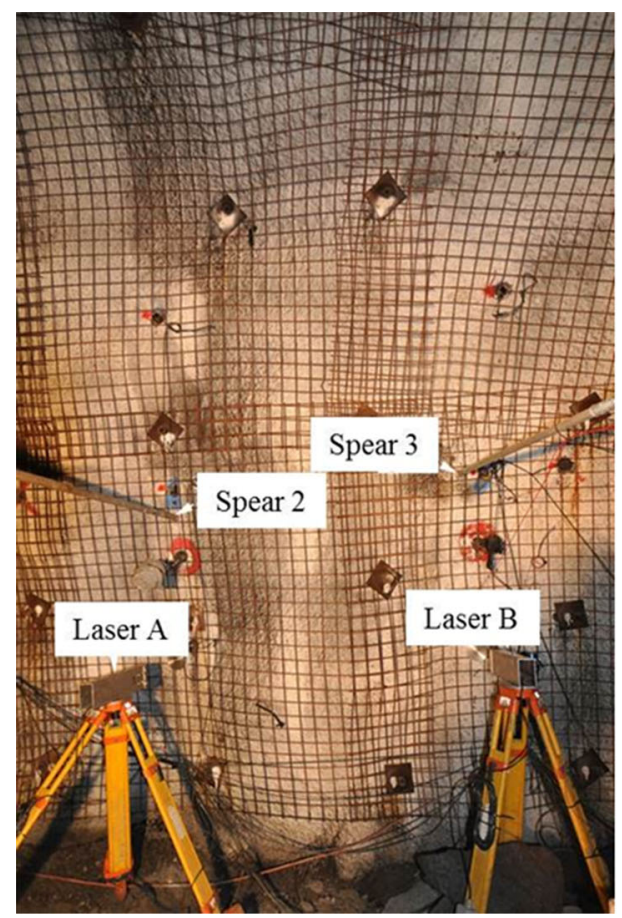

(a)

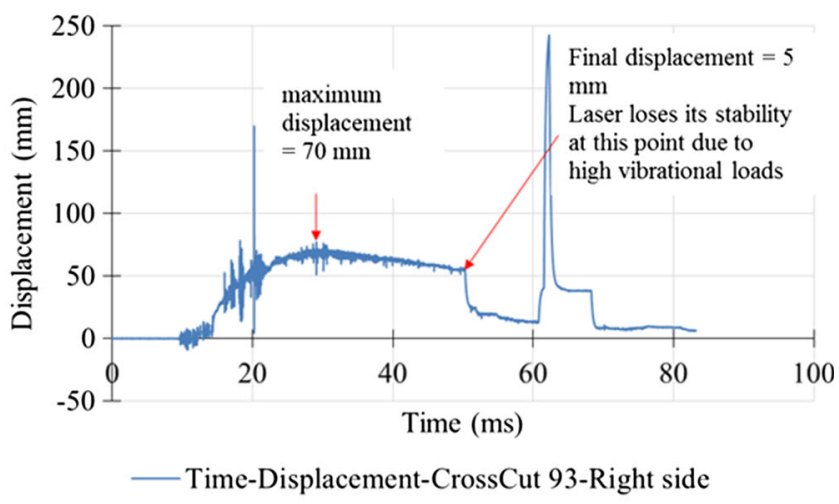

(b)

Fig. 13 a Layout of the dynamic displacement measurement in Test 2 with laser. b Displacement data measured by the left laser sensor

Table 3 Summary of the range of displacement at each charge segment

\begin{tabular}{lll}
\hline Test & $\begin{array}{l}\text { Displacement at low } \\
\text { charge segment }(\mathrm{mm})\end{array}$ & $\begin{array}{l}\text { Displacement at high } \\
\text { charge segment }(\mathrm{mm})\end{array}$ \\
\hline 1 & $3-35$ & $6-71$ \\
2 & $35-110$ & $2-110$ \\
\hline
\end{tabular}

and to estimate the gas arrival at the test wall. For this purpose, the captured video was converted into images with approximately $3.3 \mathrm{~ms}$ time interval. Figure 14 shows the position of the selected points on the first extracted frame for velocity and displacement measurements in Tests
1 and 2. Based on the analysis of the frames extracted from the video using the BlasterMass software (MREL 2000), the displacement and PPV of the high charge segment wall for the time period between the charge detonation and before gas expansion were estimated as presented in Table 4.

The arrival of gas from the blast detonation at the test wall was observed some $20 \mathrm{~ms}$ after the charge detonation in Test 1 . One explanation to the early arrival of the gas to the tested wall in Test 1 is the intersection of the observation boreholes and the boreholes in which the gas pressure sensors were installed. The other reason could be the

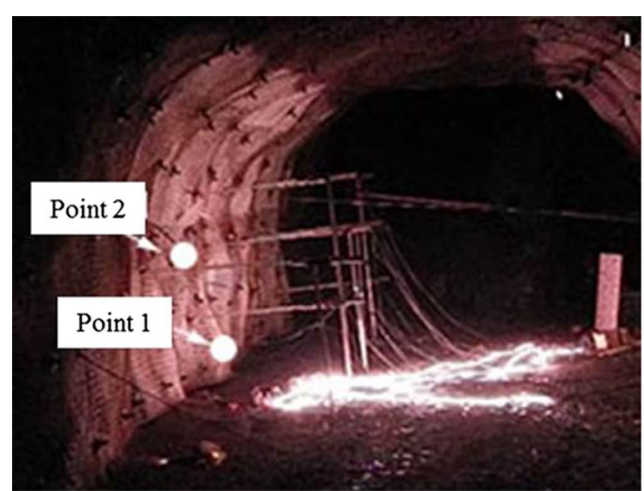

(a)

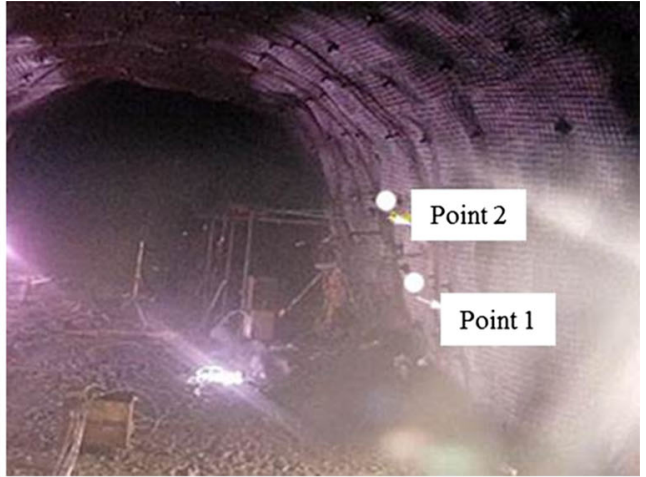

(b)

Fig. 14 Location of the selected points for PPV and displacement measurements in a Test 1 and $\mathbf{b}$ Test 2 
Table 4 Displacement and PPV measurements at points 1 and 2 in Test 1 and 2

\begin{tabular}{llll}
\hline Test & Point & Displacement $(\mathrm{mm})$ & PPV $(\mathrm{m} / \mathrm{s})$ \\
\hline 1 & 1 & 50 & 3.0 \\
1 & 2 & 30 & 2.9 \\
2 & 1 & 80 & 5.7 \\
2 & 2 & 90 & 5.7 \\
\hline
\end{tabular}

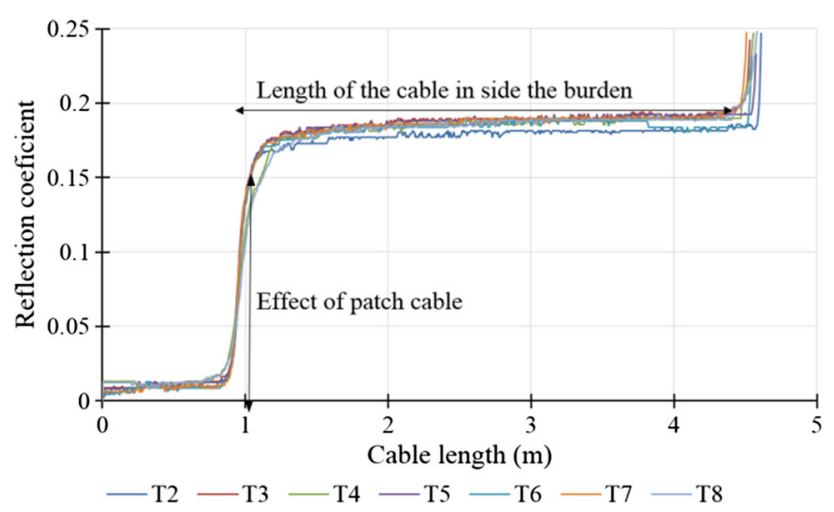

Fig. 15 Reflected wave form from coaxial cables before blast in Test 1

type of explosives used in these tests which has higher VOD compared to that of earlier tests conducted in other countries.

\subsection{Depth of Damage Measurement}

One of the parameters used to estimate the performance of the support system was the depth of damage $(t)$. As no ejection occurred and no damage to the support system could be observed in Tests 1 and 2, the rock mass was investigated to determine the depth of the failure of the rock which had failed but was retained by the support system. The depth of damage to the rock mass was investigated using two methods, the coaxial cables and the borehole camera.

The time domain reflectometry (TDR 100) (Campbell Scientific 2014) system and coaxial cables are useful in monitoring deformations and thus blast-related damage in the rock mass. A TDR 100 was connected to the coaxial cables, before and after the blast, to compare the reflected waveforms. With this method, the location of fractures in the rock mass after the blast can be identified by changes in the waveforms.

Coaxial cables with the length of $3.6 \mathrm{~m}$ were grouted into the rock mass, perpendicular to the test wall, to investigate the location of fractures and the depth of damage in the burden after the blast. The positions of the cables in the test wall are presented in Fig. 5a, b. Figure 15 shows an example of the waveforms recorded before the blasts in Test 1 . The waveforms received from the different cables were similar and comprised 3 parts. Along the first part of the cable the influence of the multiplexer as well as the patch cable is noticeable. Then the signal is stable with a reflection coefficient $\left(R_{\mathrm{C}}\right)$ of around 0.2 that can be explained from the mismatch of the TDR with $50 \mathrm{O}$ output impedance and the cable with $75 \mathrm{O}$ impedance which creates a nominal reflection coefficient:

$R_{\mathrm{C}}=\frac{\left(Z_{1}-Z_{2}\right)}{\left(Z_{1}+Z_{2}\right)}=\frac{(75-50)}{(75+50)}=0.2$

At the end, an open circuit is formed because the cable is cut at that point and there is a lack of electrical conductivity between the two conductors. This results in a difference in electrical potential between the two ends of the cable.

The waveforms reflected from the cables after the blast in Tests 1 and 2 are shown in Figs. 16 and 17. In these figures, the initial part of the curve (effects of patch cable and multiplexer) is not illustrated and only the changes in response of the parts of the coaxial cables inside the rock mass were analysed. The waveform reflected from cables $T_{1}$ and $T_{2}$ in Test 1 could not be used as the distorted signal received from the coaxial cables may indicate damage to the cable during installation. The observations and conclusions made from the recorded waveforms are summarised in Table 5.

The fractures created or re-activated at distances which were more than $1 \mathrm{~m}$ behind the support system were not considered in the estimation of the depth of failure since these fractures were close to the blasthole and they may have been created directly by the detonation. In the rockburst damage review, Stacey et al. (1995) stated that the observed thickness of the ejected material is typically in the order of $1 \mathrm{~m}$. Cable $T_{7}$ in Test 1 indicated a depth of damage of $0.9 \mathrm{~m}$. However, as the cable was located very close to the observation borehole (surveyed by a borehole camera) in which the venting of gas occurred (observed by reviewing the blast video), the depth of failure, $0.9 \mathrm{~m}$, indicated by this cable was not considered in the energy calculations as the cable could have been damaged directly by the gas expansion. The depth of failure estimated by this method in Test 1 was, therefore, limited to the recordings by cable $T_{4}(0.3-0.4 \mathrm{~m})$ at the high charge segment. The results led to the conclusion that the failure depth is $0.35 \mathrm{~m}$ at the high charge segment in Test 1 (identified fracture is assumed to be planar and parallel to the test panel). Similarly a failure depth of $0.5 \mathrm{~m}$ was detected and used for energy measurements in Test 2 at the high charge segment.

In Tests 1 and 2, four observation boreholes with $64 \mathrm{~mm}$ diameter and $3 \mathrm{~m}$ length were drilled perpendicular to the test wall before the blasts. These holes were filmed before and after the blast to detect whether new fractures had been 
(a)

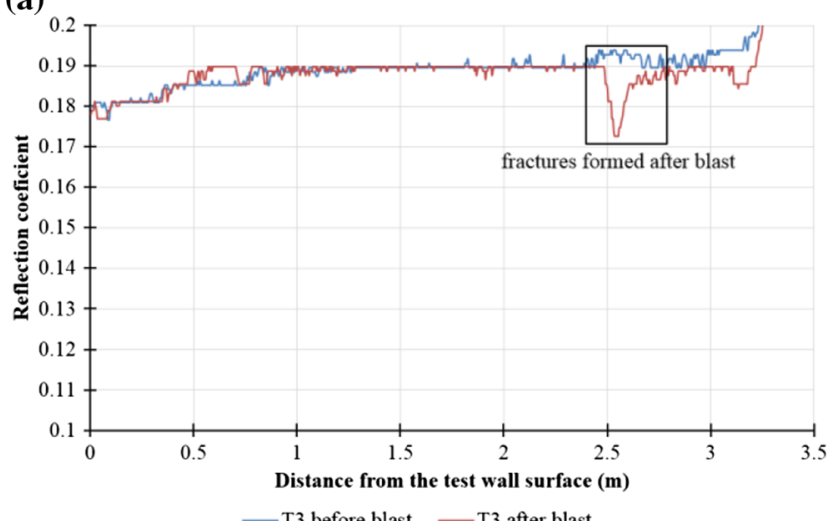

— T3 before blast _- $\mathrm{T} 3$ after blast
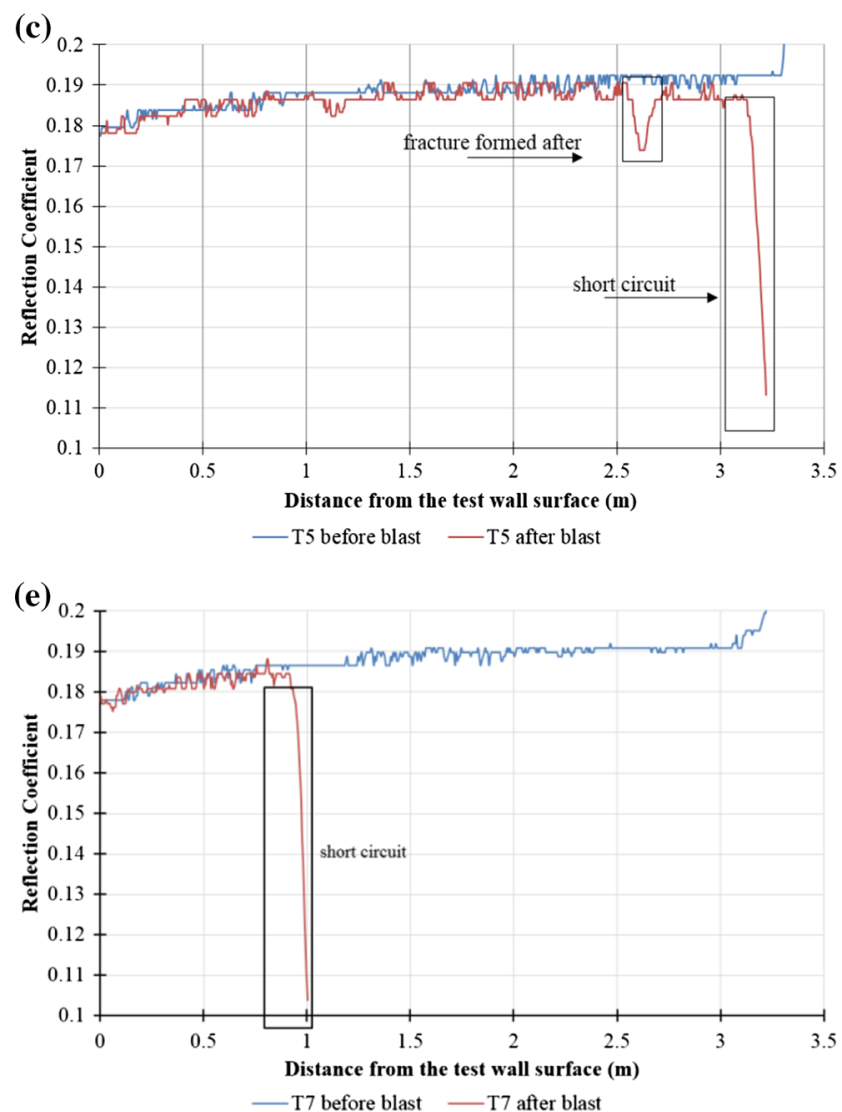

Fig. 16 Depth of failure $(t)$ measurements by coaxial cables in Tests 1

formed by the blast. The videos before blasting indicated large spacing and low frequency of joints in the burden as well as dripping water in some of the boreholes in both tests. After the blast, the boreholes were filmed again. The new videos showed that for both charge segments, the change caused by the blasting (compared to before blast) was not significant except for more particles and mud being present in the boreholes after the blast. Before conducting the energy analysis, a summary of the tests results is presented in Table 6. (b)

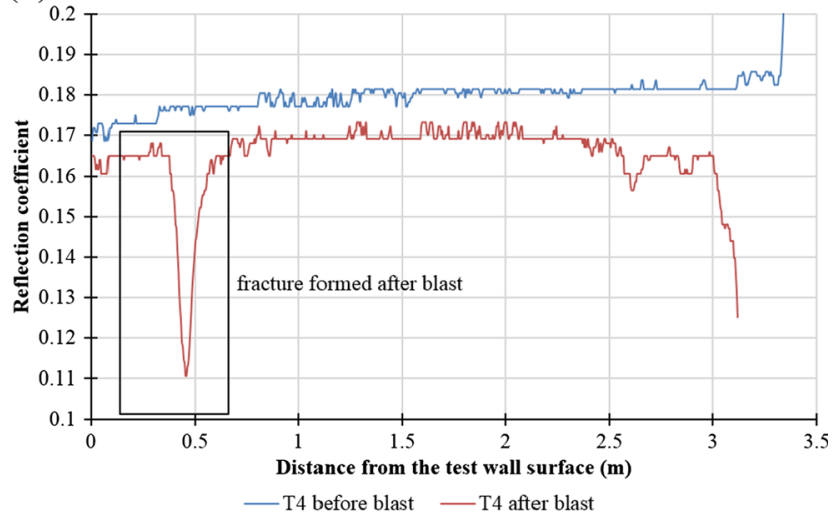

(d)
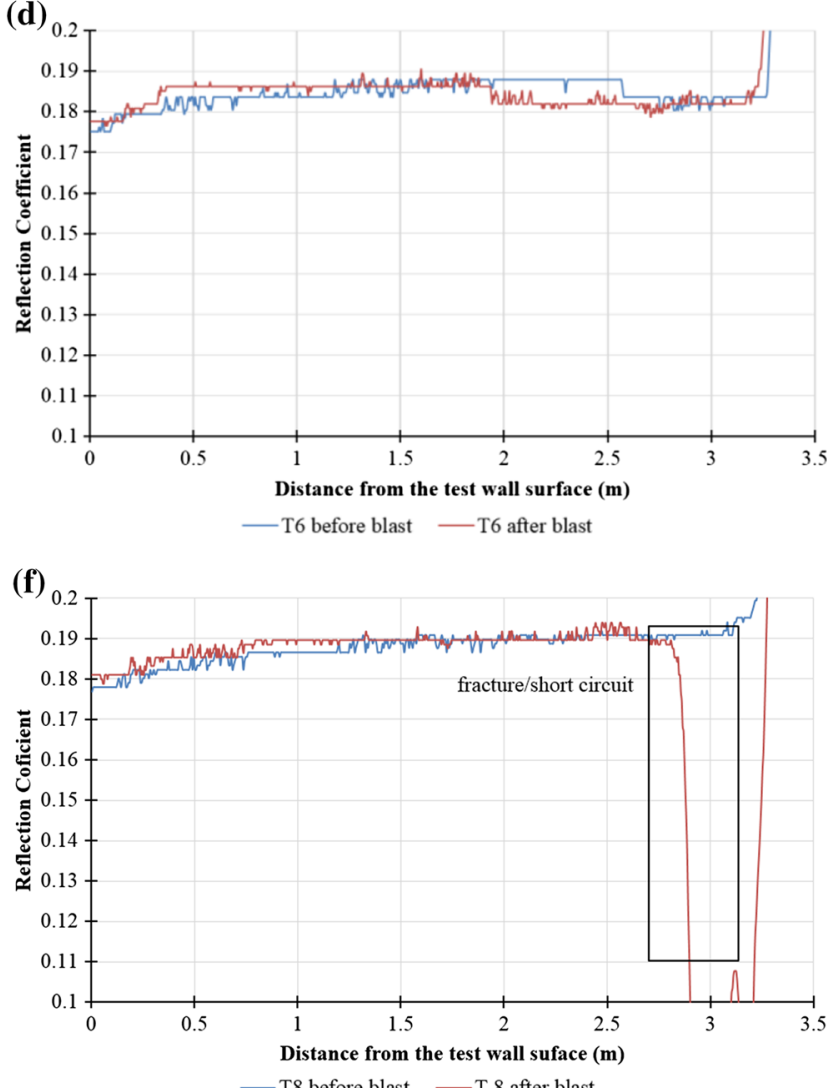

\section{Energy Analyses}

The demand on the support system from an external dynamic load is normally calculated by using the kinetic energy equation. The energy absorbed by the support components can be calculated according to their deformation or relative deformation developed during the dynamic loading. As no ejection occurred in Tests 1 and 2, the kinetic energy transmitted to the fractured zone of the test wall is calculated and compared to the energy 
(a)

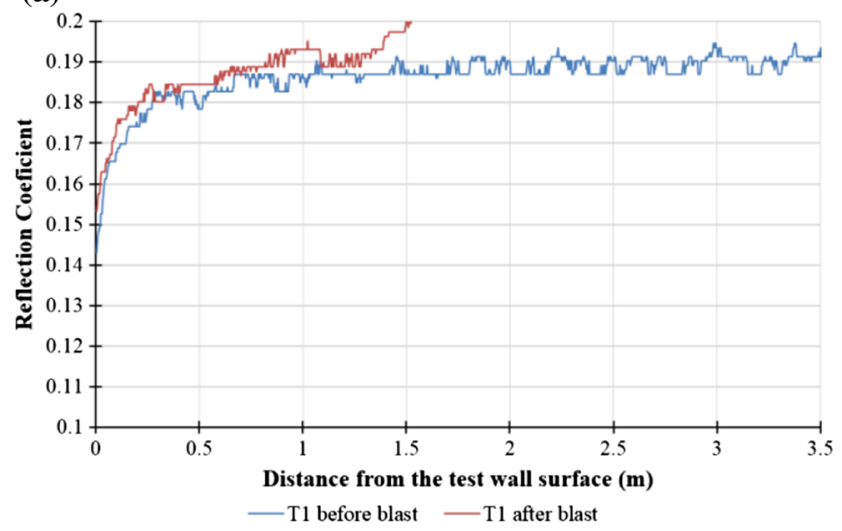

(c)

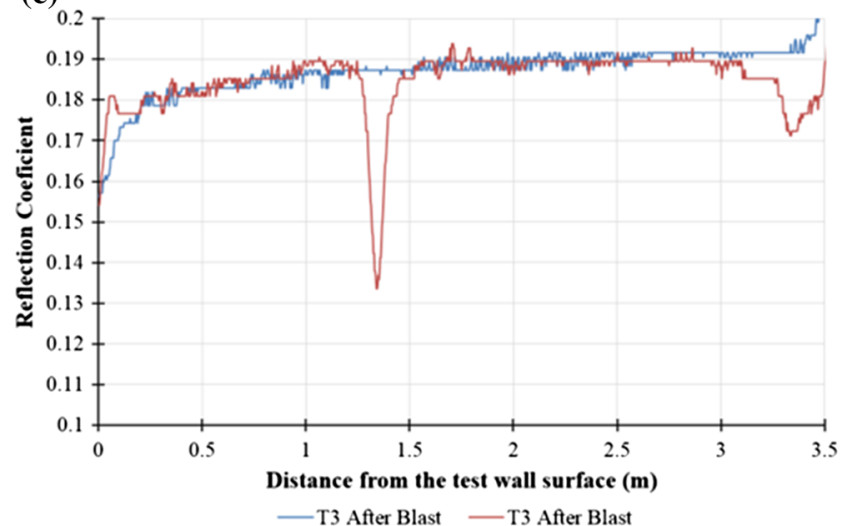

(b)

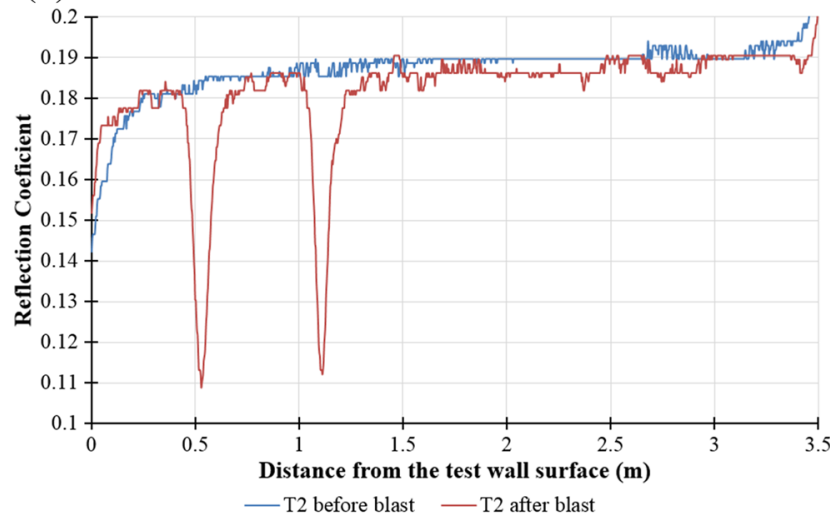

(d)

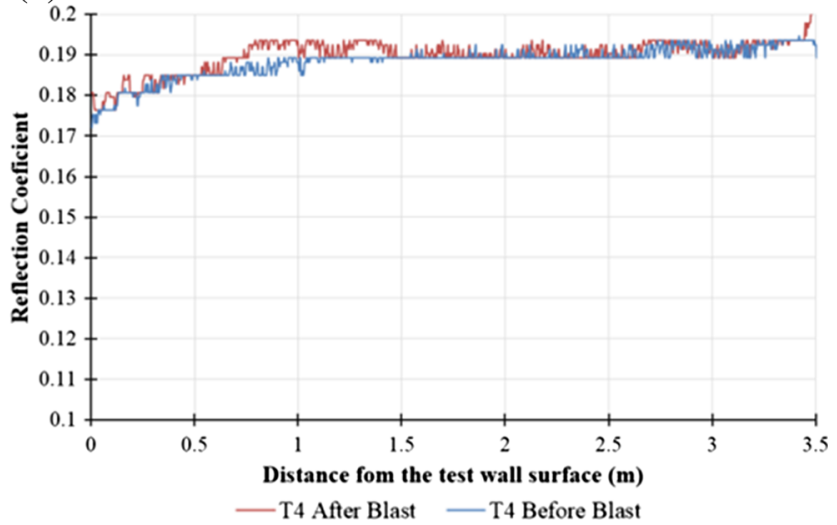

Fig. 17 Depth of failure $(t)$ measurements by coaxial cables in Tests 2

absorption by the support components to evaluate the performance of the support system.

\subsection{The Kinetic Energy}

The kinetic energy transmitted to the support system and absorbed by the surrounding rock mass and installed support system was calculated using the methods described by Kaiser et al. (1996):

$E=\frac{1}{2} \rho t v^{2}$

where, $E\left(\mathrm{~J} / \mathrm{m}^{2}\right)$ is the transmitted kinetic energy per square metre of the test wall, $v(\mathrm{~m} / \mathrm{s})$ is the PPV measured by the surface mounted accelerometers, $t(\mathrm{~m})$ is the depth of created fractures in the rock as measured by the TDR system, and $\rho\left(\mathrm{kg} / \mathrm{m}^{3}\right)$ is the rock mass density. The rock mass density was assumed to be $2800 \mathrm{~kg} / \mathrm{m}^{3}$.

The maximum possible kinetic energy per square metre of the test wall in Tests 1 and 2 is presented in Fig. 18a, b. The range of the kinetic energy was $6-20 \mathrm{~kJ} / \mathrm{m}^{2}$ in Test 1 , and $2-30 \mathrm{~kJ} / \mathrm{m}^{2}$ in Test 2 . Since no depth of failure was estimated at the low charge segment for these tests, the kinetic energy at this segment was not calculated.

\subsection{Energy Absorption by the Surface Support}

At the points of the tested wall where rockbolts were installed, the relative displacement between the rockbolt and its surrounding surface support in Tests 1 and 2 was calculated to estimate the maximum residual deflection of the surface support after the dynamic loading. In Fig. 19 the definition of the deflection of the shotcrete measured in Tests 1 and 2 is presented. The amount of relative displacement was estimated from the difference between the displacements of the rockbolt and the average displacement of the surrounding surface support. The displacements of the rockbolt and surface support were obtained from the laser scanning of the test wall, presented in Fig. 10 and Fig. 11, before and after blast. The estimation was done separately for each square metre of the test wall.

Thyni (2014) improved the standardised Round Determinate Panel (RDP) tests and applied it to the different panels of reinforced shotcrete. The testing setup is shown in Fig. 20a. He used different panels of shotcrete with different thicknesses. The energy absorption capacity of the reinforced shotcrete panels was then calculated according to the obtained load-deflection curve. Figure 20b shows the results 
Table 5 Summary of changes in cable in Tests 1 and 2 at each segment

\begin{tabular}{|c|c|c|c|}
\hline Figure & $\begin{array}{l}\text { Interpretation of wave } \\
\text { forms }\end{array}$ & $\begin{array}{l}\text { Distance from tested } \\
\text { wall surface }(\mathrm{m})\end{array}$ & Cable locations \\
\hline Figure $16 \mathrm{a}$ & Fracture & 2.5 & \multirow{2}{*}{$\begin{array}{l}\text { Within the high charge } \\
\text { segment in Test } 1\end{array}$} \\
\hline Figure $16 b$ & Fracture & $0.3-0.4 / 3.0$ & \\
\hline Figure $16 \mathrm{c}$ & Fracture/short circuit at & $2.6 / 3.1$ & \multirow{4}{*}{$\begin{array}{l}\text { Within the low charge } \\
\text { segment in Test } 1\end{array}$} \\
\hline Figure $16 \mathrm{~d}$ & No change due to blasting & - & \\
\hline Figure $16 \mathrm{e}$ & Short circuit & 0.9 & \\
\hline Figure $16 \mathrm{f}$ & $\begin{array}{l}\text { Damaged cable close to } \\
\text { the blasthole }\end{array}$ & - & \\
\hline Figure $17 \mathrm{a}$ & Open circuit & 1.5 & \multirow{2}{*}{$\begin{array}{l}\text { Within the high charge } \\
\text { segment in Test } 2\end{array}$} \\
\hline Figure $17 \mathrm{~b}$ & Fracture & 0.5 and 1.1 & \\
\hline Figure $17 \mathrm{c}$ & Fracture & 1.3 & \multirow{2}{*}{$\begin{array}{c}\text { Within the low charge } \\
\text { segment in Test } 2\end{array}$} \\
\hline Figure $17 d$ & No change due to blasting & & \\
\hline
\end{tabular}

Table 6 Summary of results in Tests 1 and 2

\begin{tabular}{|c|c|c|c|c|}
\hline & \multicolumn{2}{|l|}{ Test 1} & \multicolumn{2}{|l|}{ Test 2} \\
\hline & High charge segment & Low charge segment & High charge segment & Low charge segment \\
\hline $\mathrm{PPV}(\mathrm{m} / \mathrm{s})$ & $4.8-6.7$ & $1-4$ & $2.4-7.5$ & $2.4-6.8$ \\
\hline Depth of fracture $(\mathrm{m})$ & 0.35 & - & 0.5 & - \\
\hline Displacement range $(\mathrm{mm})$ & $6-71$ & $3-35$ & $2-110$ & $35-110$ \\
\hline
\end{tabular}

from the tests of steel fibre-reinforced shotcrete combined with weld mesh. In this figure, results from four individual panels with a thickness of $100 \mathrm{~mm}$ are presented.

The results presented in Fig. 20b were used to estimate the energy absorbed by the reinforced shotcrete and the weld mesh in Tests 1 and 2. A curve which is the average of the four curves from this series of tests was calculated to estimate the energy absorption. The corresponding absorbed energy at each charge segment per square metre of the test wall is shown in Fig. 21a, b.

The analyses of the performance of the surface support system comprising reinforced shotcrete and weld mesh indicated to maximum energy absorption of $4 \mathrm{~kJ} / \mathrm{m}^{2}$ in Test 2 with the corresponding PPV up to $7.5 \mathrm{~m} / \mathrm{s}$ and a deflection of $100 \mathrm{~mm}$ at the wall segment with a charge diameter of $98 \mathrm{~mm}$.

\subsection{Swellex Mn24}

Two accelerometers were installed at each charge segment in Test 2, 0.2 and $1.5 \mathrm{~m}$, respectively, from the surface of the shotcrete. The Swellex rockbolts closest to these accelerometers were selected for analysis of energy absorption versus displacement. A graphical presentation of the measurements is shown Fig. 22.

Table 7 summarises the geometrical data of the installed accelerometers and the Swellex rockbolts as well as the estimated displacements/deformations. The elongation of the rockbolts was estimated from the displacement measured at a depth of $1.5 \mathrm{~m}$ minus the displacement measured at $0.2 \mathrm{~m}$. At the low charge segment, an elongation of $80 \mathrm{~mm}$ was estimated. At the high charge segment, the elongation of the nearest rock bolt was less $(26 \mathrm{~mm})$ than that at the low charge segment.

Results from a series of dynamic laboratory tests on Swellex Mn24 by Voyzelle et al. (2014) was used to estimate the amount of absorbed energy by the Swellex rockbolts in Test 2. In the tests carried out by Voyzelle et al. (2014) two configurations, continuous and split tube as illustrated in Fig. 23a, were used to determine the behaviour of Swellex Mn24 under dynamic conditions. In the continuous tube configuration the bolt was installed in a steel tube and the impact load was applied directly on the bolt plate. In the split tube configuration, the bolt was installed in two separated tubes. In this setup the impact direction was parallel to the tube, at a distance from the plate.

Since the displacement measurement in Test 2 was conducted at the mid-length of the rockbolt, data from the split tube setup were considered for the estimation of the energy absorption. Results from the first drop were used since it represents a displacement similar to that observed after a single blast. The maximum $80 \mathrm{~mm}$ elongation estimated for the Swellex Mn24 in Test 2 was used in combination with the energy absorption curve in Fig. 23b. This resulted in an energy absorption of around $17 \mathrm{~kJ}$ for the Swellex MN24 for an elongation of $80 \mathrm{~mm}$. 
(a)
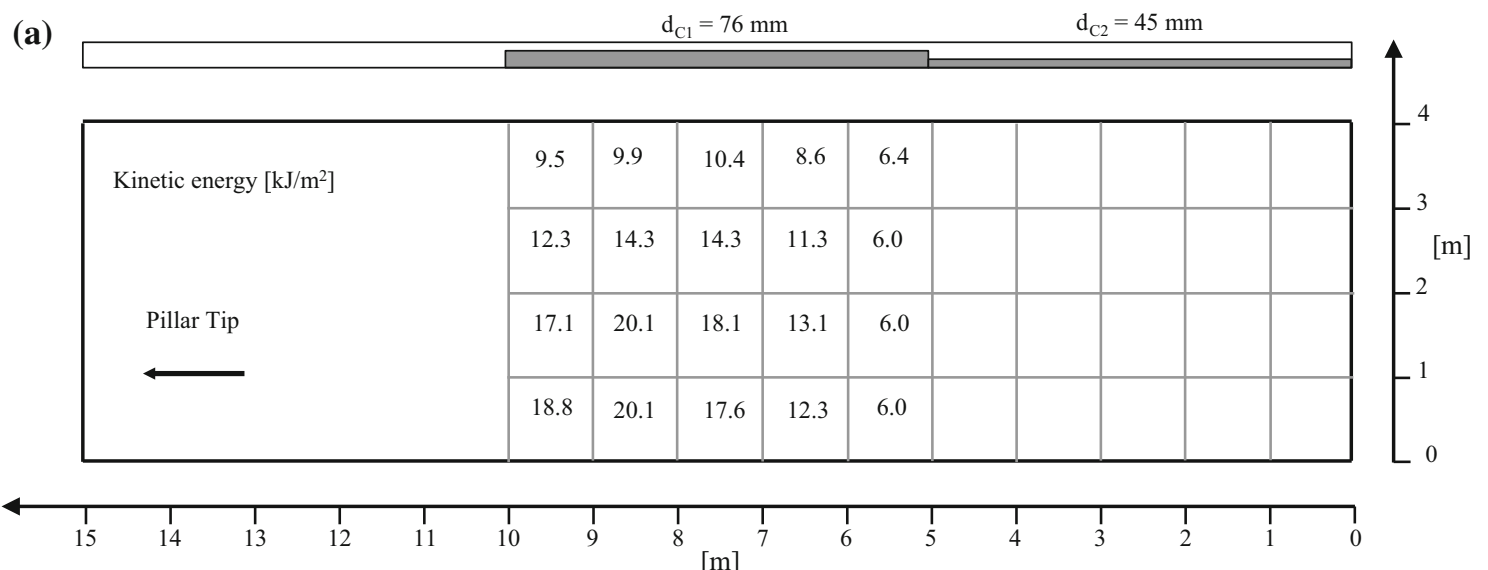

(b)
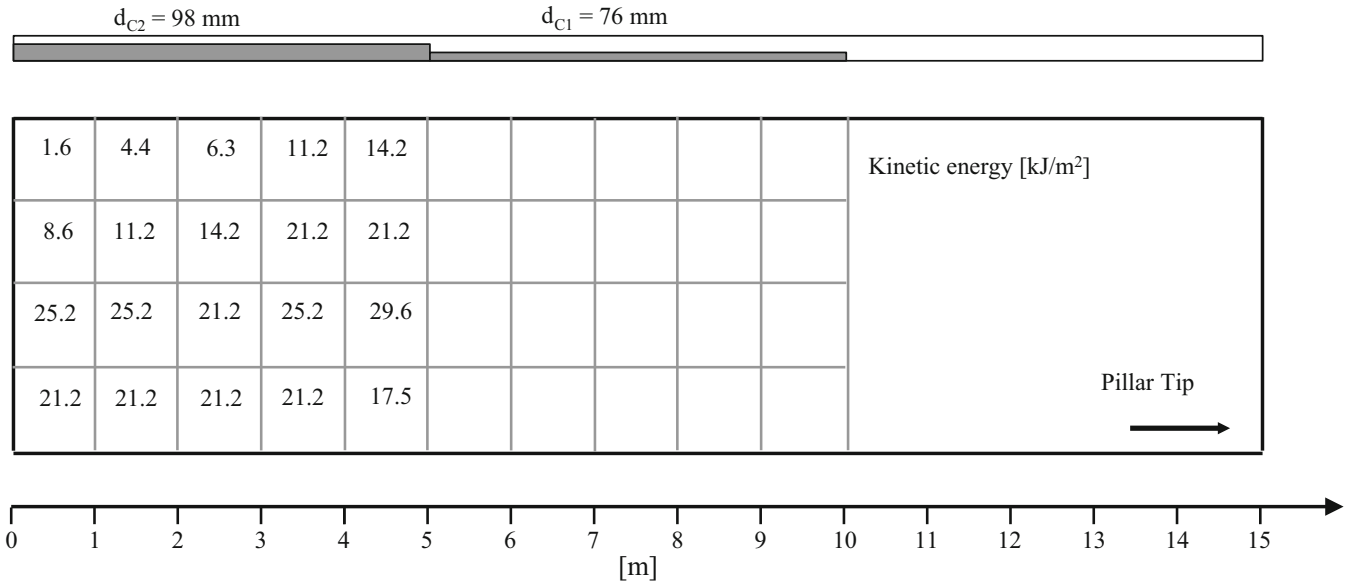

Fig. 18 Maximum possible kinetic energy at high charge segments in a Test 1 , and b Test 2, (unit: $\mathrm{kJ} / \mathrm{m}^{2}$ )

\section{Discussion}

Although it is difficult to comment with a high degree of certainty whether it was the waves, the detonation gases or a combination of them that affected the tests results, some observations from Tests 1, 2, 4 and 5 have assisted in reducing the level of uncertainty. The installation of gas pressure sensors revealed that high gas pressures were recorded at a distance of $1 \mathrm{~m}$ from the blasthole which can be due to the creation of blast-induced fractures around the blasthole. However, the sensors installed $2 \mathrm{~m}$ away from the blasthole did not record high pressure values which indicates that the blast was designed in accordance with the plans, i.e., avoiding the penetration of gases into the burden closest to the tested wall surface and therefore also the contribution to damage of the rock mass and the rock support.

In the tests conducted at Kiirunavaara mine the charge amount/concentration of the same type of explosive (NSP 711) was increased in a step by step order in Tests $1,2,4$ and 5 to determine the critical charge density resulting in damage to the support system. However, the results indicated that this was not a successful method. The increase of charge concentration in Tests 2, 4 and 5 was decided based on the results and the level of damage observed in the previous test. The increased charge concentration in Test 4 resulted in a complete destruction of the burden. In Test 5, the charge concentration was in between that of Tests 2 and 4. Also in this test complete destruction of the burden was obtained. This can be attributed to the effect of the burden. In Tests 1, 2, 4 and 5 the primary aim was to obtain a burden of around $3.5 \mathrm{~m}$. However, due to practical drilling issues there was a variation in burden of 2.8-3.9 m. This effect was observed in the results obtained in Tests 1 and 2 with burden in the range of $3.7-3.9 \mathrm{~m}$ and lower charge concentration resulting in minor damages to the support system compare to that in Tests 4 and 5. In Tests 4 and 5 the burden was in the range of 2.8-3.3 $\mathrm{m}$ and the charge concentration was higher which resulted in the destruction of the burden.

One possible explanation for the complete destruction of the burden in Tests 4 and 5 was addressed by Zhang et al. (2013) who carried out numerical back analysis of Test 5 . The analysis revealed that using high amount of explosives 


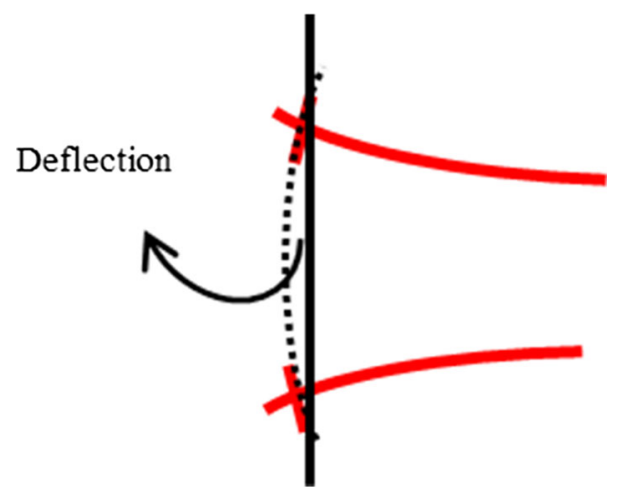

Fig. 19 Shotcrete deflection measurement in Tests 1 and 2

and a burden of $2.5 \mathrm{~m}$ to $3.5 \mathrm{~m}$ resulted in tangential stresses exceeding the tensile strength and a reduction of the radial stresses close to the wall of the cross-cut.

The second integration of the recorded acceleration along the test wall and laser scanning of the test wall was used to estimate the surface deformation. This also allowed the approximation of the amount of deformation that the tested support system sustained. The measurements helped to improve the understanding of the effect of different charge concentrations on the deformation of the supported wall. The results revealed that the identified areas of damage were mainly located within the segments with a charge diameter larger than $76 \mathrm{~mm}$. This provided a guideline for our future tests in which the minimum charge diameter should not be less than $76 \mathrm{~mm}$ for NSP 711 with a burden larger than $3.7 \mathrm{~m}$.

The acceleration data, the high-speed video, and the displacement gauges provided estimates of the particle velocity of the tested wall. By comparing the results it was concluded that the results were generally in similar order of magnitude. However, due to the lower accuracy of the displacement gauges and low resolution of the high-speed video brought on by poor lighting conditions, the range of PPV over the test wall used in the analyses was based on the integrated accelerations provided by accelerometers.

In the presented tests, high values of PPV were observed compared to those obtained in similar tests conducted in other countries, e.g., by Hagan et al. (2001) and Heal and Potvin (2007). One source of difference can be due to different instrumentation (frequency range) used in the present tests and those reported in the literature. Hildyard and Milev (2001a) explained that when measuring the PPV by geophone, the high value of damping in the geophones, or the loss of information due to filtering might be sources of error. The use of a larger number of triaxial accelerometers to identify the wave-type and record higher frequencies than those recorded by geophones was recommended by Hildyard and Milev (2001a).

The other source of difference in the PPV between the tests conducted in the Kiirunavaara mine and the tests conducted earlier in other parts of the world can be due to the selected type of explosive. In the presented tests the used explosive had a higher VOD (NSP711 with the VOD of $7931 \mathrm{~m} / \mathrm{s}$ ) than those used in the other tests. The important reason for using explosives with low VOD was according to e.g. Hagan et al. (2001) and Heal and Potvin (2007) to obtain shear waves with high amplitudes. The numerical back analysis of the large scale tests by Hildyard and Milev (2001a) revealed that despite using low VOD explosives, there was still a lack of high amplitude shear waves. This was explained to be a result of insufficient understanding of the source, and complications due to large amplitude motions and fractured state of the blasthole after detonation (Hildyard and Milev 2001a). Furthermore, in a

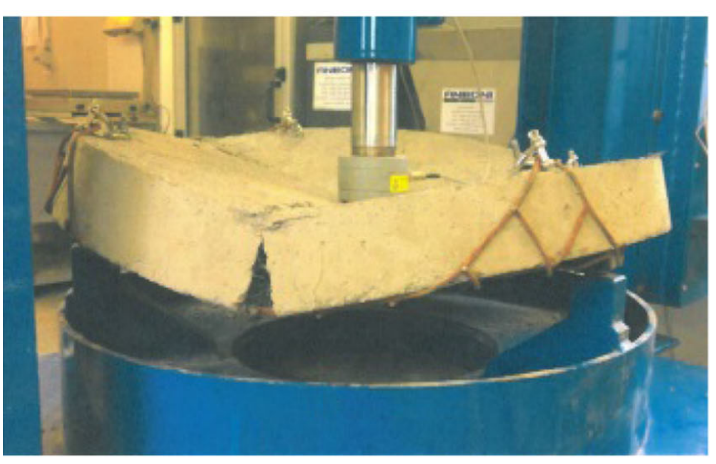

(a)

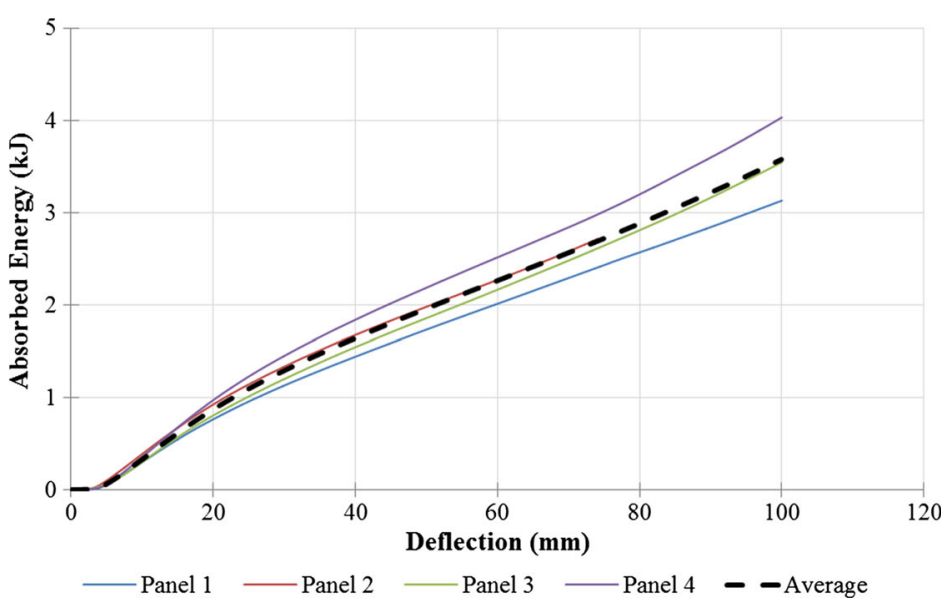

(b)

Fig. 20 a Round Determinate Panel Test at LKAB Kiirunavaara. b Energy absorption by the mesh equipped panels of $100 \mathrm{~mm}$ steel fibrereinforced shotcrete (Thyni 2014) 

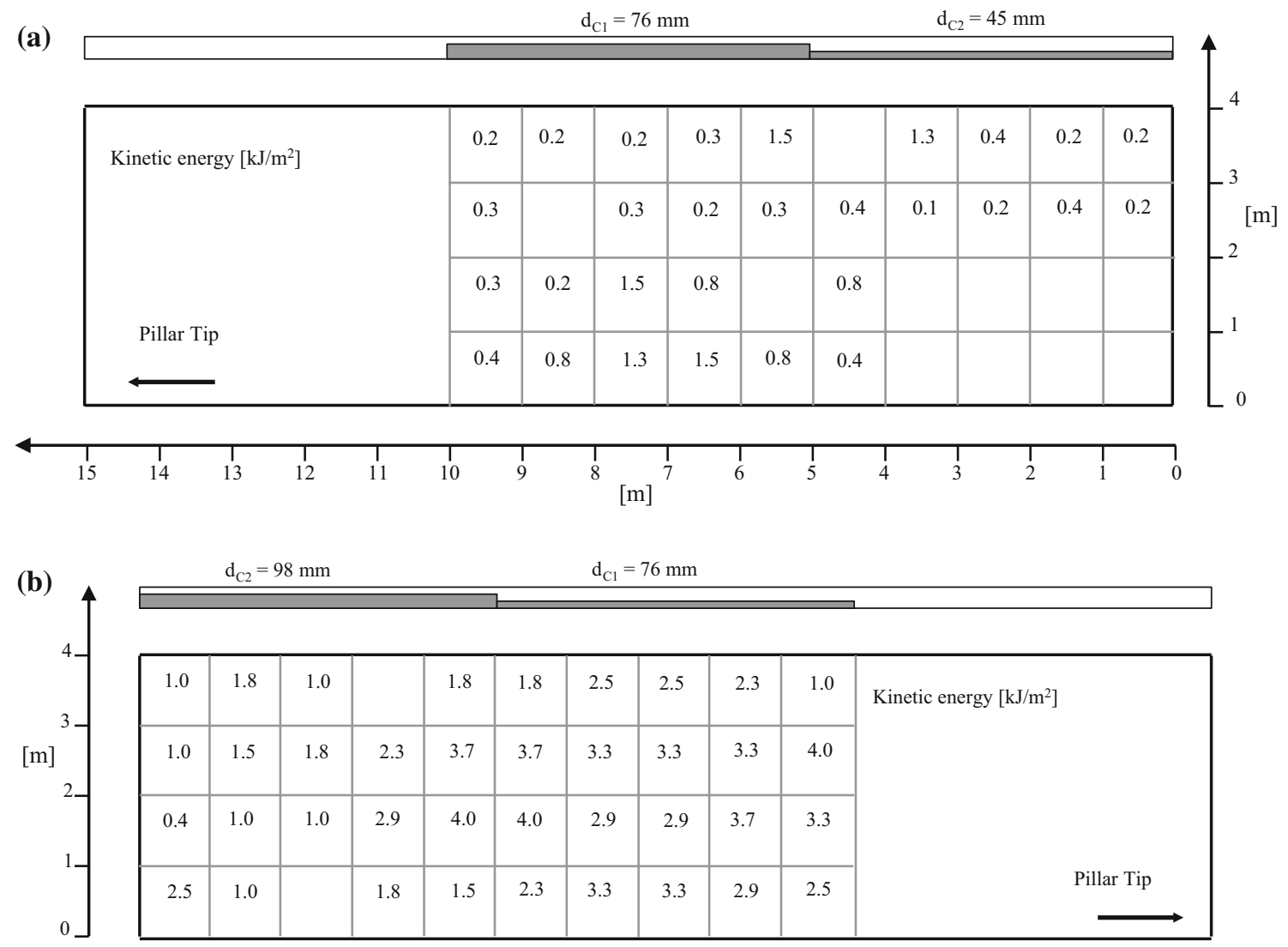

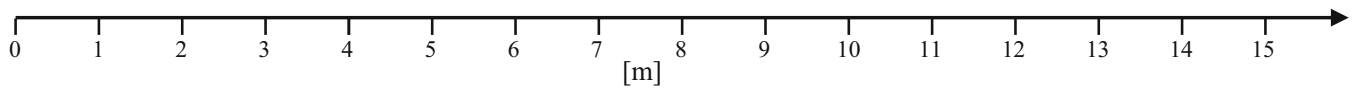

Fig. 21 Energy absorbed by reinforced shotcrete and weld mesh in $\mathbf{a}$ in Test 1 and $\mathbf{b}$ in Test 2 based on Fig. 20 (unit: kJ/m²)

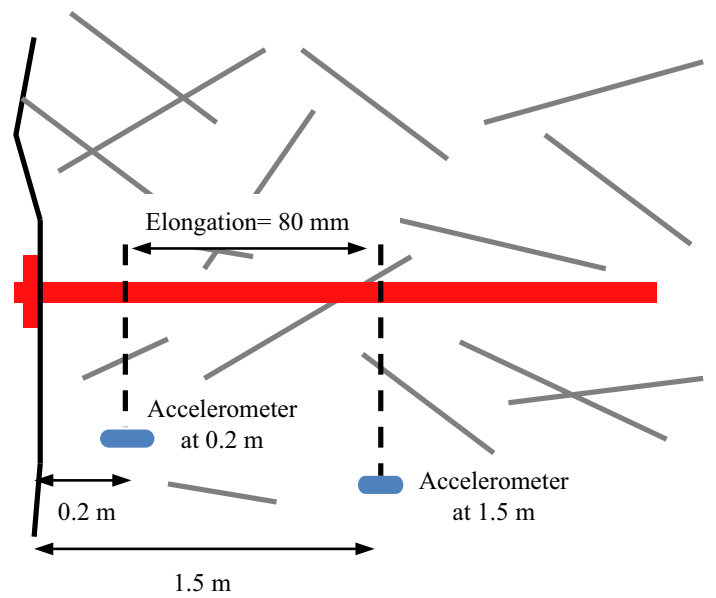

Fig. 22 Estimation of elongation of Swellex Mn24 using deep accelerometers

recent study the velocity amplification was investigated by modelling the dynamic interaction between the fractured rock and a free surface using a 1D model (Zhang et al. 2015). The results indicate that the wave frequency, fracture stiffness, fracture spacing and number of fractures (thickness of fractured zone) are the main factors which affect the velocity amplification. As a consequence, the geometrical and mechanical characteristics of the near surface rock mass of an excavation should be taken into account when assessing its local the damage potential and the rock support performance. According to (Zhang et al. 2015), the difference in rock type and geological conditions among the test sites (i.e., Kiirunavaara mine and the test sites in other countries) could be another reason for the high PPV observed in our tests.

From the post-blast observations in Tests 1 and 2 it could be concluded that the tested support system behaved quite well and withstood the strong ground motions they had been subjected to. As no ejection occurred in Tests 1 and 2, the PPV was used in the kinetic energy analysis. Therefore, the calculated energy values can only be used to estimate the maximum possible kinetic energy near the test wall surface. The calculated energy values can indicate the difference in kinetic energy between different charge concentrations. 
Table 7 Geometrical data of the installed accelerometers and the Swellex bolts and estimated displacements/deformations

\begin{tabular}{llllll}
\hline Charge segment & Accelerometer & $\begin{array}{l}\text { Installation } \\
\text { depth }(\mathrm{m})\end{array}$ & $\begin{array}{l}\text { Distance to } \\
\text { rockbolt }(\mathrm{m})\end{array}$ & $\begin{array}{l}\text { Displacement indicated } \\
\text { by accelerometer }(\mathrm{mm})\end{array}$ & $\begin{array}{l}\text { Estimated rockbolt } \\
\text { elongation }(\mathrm{mm})\end{array}$ \\
\hline Low & $A_{23}$ & 0.2 & 0.3 & 80 & 80 \\
High & $A_{22}$ & 1.5 & 0.5 & 0 & 26 \\
& $A_{17}$ & 0.2 & 0.3 & 36 & 10 \\
\hline
\end{tabular}

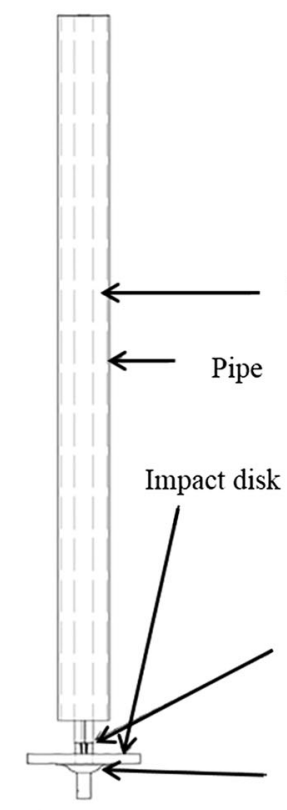

Continuous test

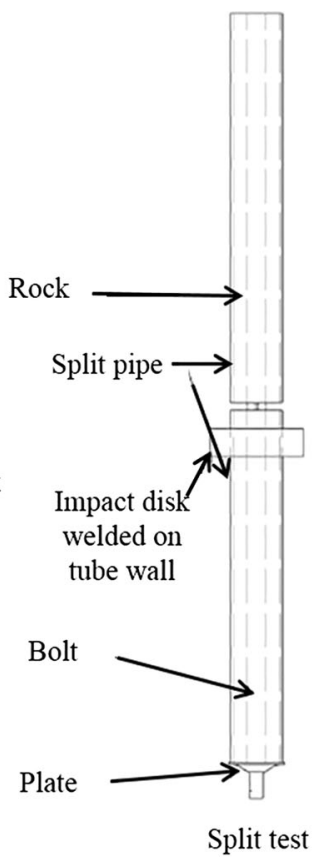

(a)

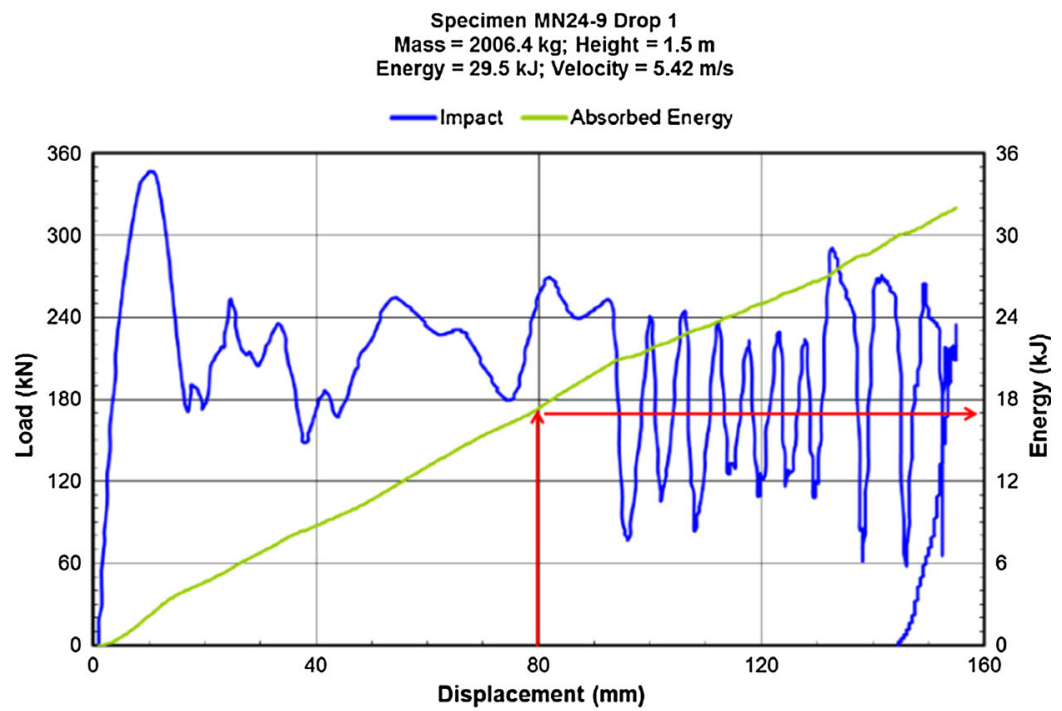

(b)

Fig. 23 a Schematic illustration of continuous and split tubes for dynamic drop test, and $\mathbf{b}$ relationship of absorbed energy and displacement from impact load for Swellex Mn24 (Voyzelle et al. 2014)

The field observations and the creation of large cracks with a width of $15 \mathrm{~mm}$ on the surface of the steel fibrereinforced shotcrete could indicate that the estimated absorbed energy was close to the final capacity of the sprayed fibre-reinforced shotcrete. When produced fractures are wider than $3-5 \mathrm{~mm}$, the short $(30 \mathrm{~mm})$ fibres will be either pulled out or ruptured and lose their functionality (Tannant et al. 1994a).

In situ dynamic testing of the weld mesh and the steel fibre-reinforced shotcrete by means of blasting has been carried out by Tannant et al. (1994a). In these tests, panels supported by only fibre-reinforced shotcrete did not maintain their adhesion with the underlying rock. In comparison, panels consisting of fibre-reinforced shotcrete and mechanical rockbolts showed far less drumminess. Tannant et al. (1994a) discussed that the rockbolts not only worked as a restraint but also assisted to maintain the rock- shotcrete bond, and as a result improved the frictional resistance of the interface. Similar interaction between the rock mass and the installed support system was observed in Test 2. Despite the creation of cracks on the surface of the shotcrete with a width of up to $15 \mathrm{~mm}$, no sign of debonding of shotcrete from the rock surface was observed on the tested wall during the visual inspections after the blast. This can be attributed to the presence of Swellex rockbolts which supported the shotcrete and prevented debonding. In tests carried out by Tannant et al. (1994a), the shotcrete generally withstood velocities of $1-2 \mathrm{~m} / \mathrm{s}$, but failed for velocities in excess of $3 \mathrm{~m} / \mathrm{s}$. In the presented test, the support system resisted velocities up to $7.5 \mathrm{~m} / \mathrm{s}$. One possible explanation for the noticeable difference could be the weld mesh installed over the reinforced shotcrete helping to transfer load more uniformly between the rockbolts. Heal and Potvin (2007) concluded based on 
their in situ test results that the ground support systems without mesh can be expected to fail at energy levels of around $1.5-2 \mathrm{~kJ} / \mathrm{m}^{2}$ while those with mesh can be expected to fail at energy levels of around $5-8 \mathrm{~kJ} / \mathrm{m}^{2}$.

The performance of the fibre-reinforced shotcrete and weld mesh was evaluated by measuring the deflection of the installed surface support and estimating the energy absorption at each square metre of the test wall. The estimated absorbed energy for the measured deflection was calculated using deflection-energy absorption curves provided by Thyni (2014) based on static round determinate panel tests at LKAB. The performance of the Swellex rockbolt was investigated by estimating the elongation of one rockbolt and relating the result to the absorbed energydisplacement from impact loads on Swellex Mn24 by Voyzelle et al. (2014). By comparing the maximum estimated energy absorption by the Swellex $\left(17 \mathrm{~kJ} / \mathrm{m}^{2}\right)$ and the fibre-reinforced shotcrete $\left(4 \mathrm{~kJ} / \mathrm{m}^{2}\right)$ to the maximum kinetic energy $\left(30 \mathrm{~kJ} / \mathrm{m}^{2}\right)$, it can be assumed that as the support system is still functional, some of the energy is reflected back to the surrounding rock.

\section{Conclusions}

This paper presents the results from the development of a large scale dynamic testing method of rock support systems which uses blasting to generate the dynamic load. This was done by using different charge concentrations while the burden and explosive type was kept constant. An additional objective was to avoid damage from detonation gases. The combination of the different types of monitoring instruments and the damage mapping provided valuable information about the performance of the rock mass and the rock support system during these tests. The major conclusions of this work are:

- It is possible to minimise the effect of gas expansion from blasting by using high impact, low gas explosives (e.g., military type explosive used in these tests), avoiding stemming the blasthole, and leaving a "reasonable" burden.

- It is crucial to have a "reasonable" burden for a successful simulated rockburst test. Too small burden can result in severe damage to the tested wall caused by the gas expansion. Large burdens will allow significant stress wave attenuation and the energy transmitted to the rock support system will be too low to expose the rock support system beyond its bearing capacity. It is desirable to conduct several field tests together with numerical modelling to design a "reasonable" burden.

- From the estimated PPV values it can be concluded that it is insufficient to use only the PPV to assess the damage level of the support system and the rock mass. Damage assessment in Tests 1 and 2 showed that the rock support was not at all or just slightly damaged even though the PPV had reached $7.5 \mathrm{~m} / \mathrm{s}$, which is arguably a high value compared to the previous tests conducted in other countries.

- The comparison of maximum estimated energy absorbed by the installed Swellex and the fibrereinforced shotcrete with the maximum estimated kinetic energy shows that the wave energy is partly absorbed during the fracturing of the rock mass, fracturing of the shotcrete, sliding of rockbolts, yielding of the mesh, and partly reflected to the surrounding rock mass.

The large amount of data recorded during these trials will be useful for the calibration of more advanced numerical models. The numerical analyses can then be used for sensitivity analyses simulating different blast designs. This will be useful for improving the design of the tests. Based on the results from preliminary numerical analysis of earlier Tests 1, 2, 4 and 5, an additional large scale dynamic test, Tests 6 , is planned to be conducted in the LKAB Kiirunavaara mine. Results and numerical analysis of Test 6 will be presented in form of a separated publication.

Acknowledgments This work was financially supported by LKAB, Boliden and Centre of Advanced Mining and Metallurgy at LTU (CAMM) which are gratefully acknowledged. The LKAB Mining Company in Kiruna is gratefully acknowledged for providing the opportunity to conduct the tests at this mine. The personnel Lars Malmgren, Anders Nordqvist, Jimmy Töyrä and Ulf Bertil Andersson at LKAB and Ulf Nyberg at LTU are gratefully acknowledged for their practical assistance for site preparations and conducting the Test 1 to Test 5 .

Open Access This article is distributed under the terms of the Creative Commons Attribution 4.0 International License (http://crea tivecommons.org/licenses/by/4.0/), which permits unrestricted use, distribution, and reproduction in any medium, provided you give appropriate credit to the original author(s) and the source, provide a link to the Creative Commons license, and indicate if changes were made.

\section{References}

Andersson UB (2010) Geology and Structures for Level Z741 Blocks 9 and 12. Internal Report LKAB Kiruna, Sweden, p 10

Andersson UB (2011) Tättkartering runt skjutskador ort 93 oh 95 Z741. Internal Report LKAB Kiruna, Sweden, p 2

Andrieux PP, Turichshev A, ÓConnor CP, Brummer RK (2005) Dynamic Testing With Explosive Charges of Rockburst-Resistant Ground Support Systems at the Fraser Nickel Mine. Report to Falconbridge Limited Mine Technical Services, Final Version, September 2005 Itasca Consulting Company Inc. Sudbury, Canada, p 103 
Ansell A (2004) In situ testing of young shotcrete subjected to vibrations from blasting. Tunn Undergr $\mathrm{Sp}$ Technol 19(6):587-596

Archibald JF, Baidoe JP, Katsabanis PT (2003) Rockburst damage mitigation benefits deriving from use of spray-on rock lining. In: Proceeding of third international seminar on surface support liners: Thin spray-on liners, shotcrete and mesh, Université Laval, Quebec City, Canada, August 2003 Section 19

Ekström M, Ekström T (1997) Petrografisk beskrivning av sidoberget i Kiirunavaara. Ekström Mineral Ab Stockholm, p 21

Espley SJ, Heilig J, Moreau LH (2002) Assessment of the dynamic capacity of liners for application in highly-stressed mining environments at INCO Limited. In: Proceedings of the international seminar on surface support liners, Johannesburg, South Africa, 29-31 July 2002

Geijer P (1910) Igneous rocks and iron ores of Kiirunavaara and Tuolluvaara: Scientific and practical researches in Lapland. Luossavaara-Kiirunavaara Aktiebolag Stockholm, p 278

Hadjigeorgiou J, Potvin Y (2008) Overview of Dynamic testing of Ground Support. In: Potvin Y (ed) Proceeding of the 4th international seminar on 'Deep and high stress mining. Australian center for Geomechanics, Perth, pp 349-371

Hagan TO, Milev AM, Spottiswoode SM, Hildyard MW, Grodner M, Rorke AJ, Finnie GJ, Reddy N, Haile AT, Le Bron KB (2001) Simulated rockburst experiment-an overview. J S Afr Inst Min Metall 101(5):217-222

Haile A, Le Bron K (2001) Simulated rockburst experimentevaluation of rock bolt reinforcement performance. J S Afr Inst Min Metall 101(5):247-252

Heal D (2010) Observations and analysis of incidences of rockburst damage in underground mines. Doctor of Philosophy of Civil and Resource Engineering, School of Civil and Resource Engineering, University of Western Australia

Heal D, Potvin Y (2007) In-situ Dynamic Testing of Ground Support Using Simulated Rockburst. In: Potvin Y (ed) Proceeding of fourth international seminar on 'deep and high stress mining'. Australian Centre for Geomechanics, Perth, pp 373-394

Heal D, Hudyma M, Langille C, Potvin Y, Butcher R, Ball R, Hartmann B (2005) In-situ testing of ground support performance under strong dynamic loading. In: Potvin Y, Hudyma M (eds) Proceedings of the 6th international symposium on rockbursts and seismicity in mines. Australian Centre for Geomechanics, Perth, pp 85-94

Helte A, Lundgren J, Örnhed H, Norrefeldt M (2006) Prestandabestämning av svensk sprängdeg m/46. Report nr FOI-R-2051SE Stockholm

Hildyard MW, Milev AM (2001a) Simulated rockburst experiment: numerical back-analysis of seismic wave interaction with the tunnel. J S Afr Inst Min Metall 101(5):223-234

Hildyard M, Milev A (2001b) Simulated rockburst experiment: development of a numerical model for seismic wave propagation from the blast, and forward analysis. J S Afr Inst Min Metall 101(5):235-246

Kaiser PK, MacCreath DR, Tannant DD (1996) Canadian rockburst support handbook. Geomechanics Research Centre, Sudbury

Malmgren L (2005) Interaction between shotcrete and rockexperimental and numerical study. Doctoral thesis, Luleå University of Technology

Malmgren L (2010) Ductile rock bolt for rock burst applications. Report nr LF110076 LKAB Kiruna, Sweden, p 21
Milev AM, Spottiswoode SM, Rorke AJ, Finnie GJ (2001) Seismic monitoring of a simulated rockburst on a wall of an underground tunnel. J S Afr Inst Min Metall 101(5):253-260

MREL G (2000) Blaster's MAS [computer program]. Version 3.0. Ontario, Canada: MREL specialty explosive products limited

Olsson M, Nyberg U, Fjelborg S (2009) Controlled fragmentation in sublevel caving-first tests. Report 2009:2 ISSN 1653-5006 Swebrec Stockholm, p 49

Ortlepp WD (1969) An empirical determination of the effectiveness of rockbolt support under impulse loading. In: Brekke TL, Jorstad FA (eds) Proceedings of the international symposium on large permanent underground openings. Universitats, forlaget, Oslo, pp 197-205

Ortlepp WD (1992) Implosive-load testing of tunnel support. In: Kaiser PK, McCreath DR (eds) Rock support in mining and underground construction. Balkema, Rotterdam, pp 675-682

Potvin Y, Wesseloo J, Heal D (2010) An interpretation of ground support capacity submitted to dynamic loading. In: Van Sint Jan M, Potvin Y (eds) Proceedings of the 5th international seminar on deep and high stress mining. Australian Center for Geomechanics, Santiago, pp 251-272

Reddy N, Spottiswoode SM (2001) The influence of geology on a simulated rockburst. J S Afr Inst Min Metall 101(5):267-274

Rorke AJ, Milev AM (1999) Near field vibration monitoring and associated rock damage. In: FRAGBLAST 1999, South African Institute of Mining and Metallurgy, Johannesburg, 8-12 August 1999

Stacey T (2012) A philosophical view on the testing of rock support for rockburst conditions. J S Afr Inst Min Metall 112(8):01-08

Stacey T, Ortlepp W, Kirsten H (1995) Energy-absorbing capacity of reinforced shotcrete, with reference to the containment of rockburst damage. J S Afr Inst Min Metall 95(3):137-140

Tannant DD, McDowell GM, McCreath DR (1994a) Shotcrete performance during simulated rockbursts. In: IVth south american congress on rock mechanics, workshop on applied rockburst research, (SOCHIGE), Santiago, pp 241-248

Tannant D, Brummer R, Kaiser P (1994b) Response of rockbolts to nearby blasts. In: International workshop on applied rockburst research, pp 257-264

TDR 100-Time Domain Reflectometer [Internet]; c (2014). Available from: https://www.campbellsci.com/tdr100

Thyni F (2014) Design of Shotcrete for Dynamic Rock Support by Static Testing. Master Thesis, Luleå University of Technology

Voyzelle B, Anderson T, Quesnel S, Eagleson R, Trottier J (2014) Laboratory Testing of Static and Dynamic Behaviours of Atlas Copco MN24 Swellex Bolts. Canmet mining project P-001335.001

Zhang P, Yi CP, Nordlund E, Shirzadegan S, Nyberg U, Malmgren L, Nordqvist A (2013) Numerical back analysis of simulated rockburst field tests by using coupled numerical technique. In: Potvin Y (ed) Proceeding of seventh international symposium on ground support in mining and underground construction. Australian centre for Geomechanics, Perth, pp 565-585

Zhang P, Swan G, Nordlund E (2015) 1D numerical simulation of velocity amplification of P-wave travelling through fractured rock near a free surface. J S Afr Inst Min Metall 115:1121-1126 